Full Length Articles

\title{
Winners and losers from sovereign debt inflows
}

\author{
Fernando Broner ${ }^{\mathrm{a}}$, Alberto Martin ${ }^{\mathrm{b}}$, Lorenzo Pandolfi ${ }^{\mathrm{c}}$, Tomas Williams ${ }^{\mathrm{d}, *}$ \\ a CREi, Universitat Pompeu Fabra, Barcelona GSE, Spain \\ b CREi, Barcelona GSE, Spain \\ ${ }^{\mathrm{C}}$ University of Naples Federico II and CSEF, Italy \\ d George Washington University, United States of America
}

\section{A R T I C L E I N F O}

\section{Article history:}

Received 24 August 2020

Received in revised form 18 December 2020

Accepted 27 January 2021

Available online 8 February 2021

Repository data link: https://data.mendeley. com/datasets/rvz7k5j8g2/1

\section{JEL classification:}

F31

F32

F36

G15

G23

Keywords:

Sovereign debt

Capital inflows

Exchange rate

Government yields

Stock prices

Emerging markets

\section{A B S T R A C T}

We study the effects of sovereign debt inflows on domestic firms. To do so, we exploit episodes of large sovereign debt inflows, which follow the announcements of the inclusion of six emerging countries into major sovereign debt indexes. We find that these events reduce government bond yields, appreciate the domestic currency, and have heterogeneous stock-market effects on domestic firms. Firms operating in tradable industries experience lower returns than firms in non-tradable industries. In addition, financial firms, government-related firms, and firms that rely more on external financing experience higher returns. The effect on financial and government-related firms is stronger in countries that display larger reductions in government bond yields. The effect on tradable firms is stronger in countries that display stronger appreciations. We provide a stylized model that rationalizes these results. Our findings shed novel light on the channels through which sovereign debt inflows affect firms in emerging countries. (C) 2021 Published by Elsevier B.V. This is an open access article under the CC BY-NC-ND license (http://creativecommons.org/licenses/by-nc-nd/4.0/).

\footnotetext{
We are grateful to Linda Tesar (Editor), Anusha Chari and Anna Pavlova for their insightful discussions at the 43rd Annual NBER International Seminar on Macroeconomics (ISoM). We also received helpful comments from Graciela Kaminsky, Tommaso Oliviero, Marco Pagano, Giovanni W. Puopolo, Stefano Rossi, Tom Schmitz, Annalisa Scognamiglio, Saverio Simonelli, seminar participants at the Bank of Italy, and participants at the III Interdisciplinary Sovereign Debt Research and Management Conference (DebtCon3), the XV CSEF-IGIER Symposium on Economics and Institutions, the 43rd Annual NBER ISoM, the 2020 Annual Meeting of the American Economic Association, and the XXI Workshop on Quantitative Finance. We thank Colton Larson and Genna Tatu for excellent research assistance, and Mariano Cosentino for his help in the preparation of the dataset. Pandolfi and Williams acknowledge support from the Einaudi Institute for Economics and Finance (2017 EIEF research grant) and the Columbian College Facilitating Fund from George Washington University. Broner and Martin acknowledge support from the Spanish Ministry of Economy, Industry, and Competitiveness through the I + D Excelencia grant (ECO2016-79823-P), the Spanish Ministry of Science and Innovation through the Severo Ochoa Programme for Centers of Excellence in R\&D grant (CEX2019-000915-S), the Generalitat de Catalunya (AGAUR grant 2017-SGR0-1393), the CERCA Programme/ Generalitat de Catalunya, and the Barcelona GSE Research Network. Martin also acknowledges support from the European Research Council under EU Seventh Framework Programme (FP7/2007-2013) ERC Consolidator Grant (615651-MacroColl). The views are those of the authors and not of the European Central Bank.

* Corresponding author.
}

E-mail address: tomaswilliams@gwu.edu. (T. Williams). 


\section{Introduction}

Financial globalization in emerging economies has increased remarkably over the last two decades. Loosening of capital controls and investors' search for yield in times of low interest rates contributed to an upsurge in foreign investment in emerging asset markets. Local-currency sovereign-debt markets, in particular, experienced an unprecedented rise in international investors' participation. Since the Global Financial Crisis, the share of emerging countries' local currency sovereign debt held by foreign investors more than doubled, from about $10 \%$ in 2009 to $25 \%$ in (BIS, 2019).

The increased participation of foreigners in domestic sovereign debt markets is believed to have significant effects on the recipient economies. Yet, the exact nature of these effects is unclear. For instance, small-open economy models with full financial integration leave little or no role for shocks to the foreign demand for domestic assets. ${ }^{1}$ But recent studies argue that these shocks do affect sovereign bond yields and exchange rates. ${ }^{2}$ These studies depart from the standard assumption of perfect financial markets by introducing frictions such as market segmentation and limited arbitrage. According to this view, as long as domestic financial markets are not perfectly integrated in international markets, an increase in foreign demand for domestic sovereign debt leads to net capital inflows. These inflows, in turn, affect domestic firms through their effects on interest and exchange rates. ${ }^{3}$ These effects are likely to be heterogeneous depending, for instance, on whether a firm operates in a tradable sector or is financially dependent.

Assessing the channels through which sovereign debt inflows affect domestic firms is challenging from an empirical point of view. The main reason is that sovereign debt flows are endogenous to macroeconomic conditions. For instance, favorable macroeconomic conditions (e.g. due to positive technological or political shocks) are likely to reduce sovereign risk, improve fundamentals, and attract foreign investors. Hence, the mere correlation between sovereign debt inflows and the value of domestic firms cannot be interpreted as evidence of a causal relationship.

To overcome this difficulty, we exploit episodes of large sovereign debt inflows to six emerging countries (Colombia, Czech Republic, Mexico, Nigeria, Romania, and South Africa). Specifically, we take advantage of the sudden and unanticipated announcements of these countries' inclusion in two major sovereign debt indexes: the Citigroup World Government Bond Index (WGBI) and the J.P. Morgan Government Bond Index Emerging Markets (GBI-EM). These indexes represent two of the most widely tracked benchmarks for international investors in local currency sovereign debt markets. Because of this, the announcement of a country's inclusion in such an index induces a large rebalancing in the portfolios of international investors who, in order to replicate the composition of the index, increase their demand for the country's local-currency sovereign debt.

These announcements provide an ideal setting to study the effects of sovereign debt inflows. First, they trigger large inflows which are specific to the sovereign debt markets of newly included countries: as the two indexes are exclusively composed of sovereign bonds, their rebalancing only entail inflows to sovereign bond markets and not to equity nor corporate debt markets. Second, the dates in which index providers announce the inclusions are not anticipated by investors, nor do they coincide with important news about the economy of included countries or with major policy changes. Thus, these features allow us to adopt an event study methodology - which exploits the unexpected timing of the announcements - to assess the impact of sovereign debt inflows on the cost of government debt, the domestic currency, and the stock market returns of domestic firms.

Our results are as follows. In the two days following the announcements, 5-year local currency sovereign bond yields drop significantly in all countries, by an average of 32.5 basis points. In the same window, moreover, the domestic currency appreciates by an average of $1.1 \%$ age points. Domestic firms' stock prices also respond significantly and heterogeneously to the announcements, as shown in Fig. 1. The stock price of financial and government-related firms increases sharply in the first trading day following the announcements. Instead, the market value of firms operating in tradable sectors remains stable. Importantly, while prices of all these firms are on the same trend in the 7 trading days prior to the episodes, they clearly diverge in the dates of the announcements. Further, this divergence persists even 20 trading days after the announcements.

To assess the economic magnitude of these heterogeneous effects, we analyze how abnormal returns of firms evolve after each announcement episode in a series of regressions in which we can control for potential overlap between different firm categories and for firms' dependance on external financing. These regressions show that financial and government-related firms experience larger than average cumulative abnormal returns (CARs) in the two days following the announcements, while tradable firms experience lower than average CARs. Additionally, we find that CARs are larger for firms in more financially constrained industries.

We conjecture that these effects of sovereign debt inflows are largely driven by changes in sovereign bond yields and exchange rates. Indeed, we show that the changes in sovereign bond yields and exchange rates in the two days following the announcements are correlated with the size of the inflows implied by portfolio rebalancing. Moreover, we find that the effect on financial and government-related firms is more pronounced in countries that experience larger reductions in the sovereign bond yield. Similarly, tradable firms are more affected by the announcements in countries that experience a larger appreciation. Quantitatively, sovereign debt inflows that lead to a reduction of 100 basis points in the 5-year local-currency government bond

\footnotetext{
1 For example, in models of exchange rates determination based on uncovered interest parity, such as Obstfeld and Rogoff (1995), portfolio flows do not affect the equilibrium exchange rates, as noted in Gabaix and Maggiori (2015).

2 Gabaix and Maggiori (2015) show theoretically that capital inflows can appreciate the currency of recipient countries as long as international financial intermediaries have limited risk-absorbing capacity. Du and Schreger (2016) argue that local-currency sovereign-debt markets are typically not internationally integrated, so that clientele demand shocks are important determinants of local currency sovereign bond prices.

${ }^{3}$ Consistent with this, Pandolfi and Williams (2019) provide empirical evidence that sovereign debt inflows lead both to an appreciation of the exchange rate and a reduction in local-currency sovereign yields. Relatedly, Hofmann et al. (2019) find that currency appreciations in emerging economies are often contemporaneous to reductions in government bond yields.
} 


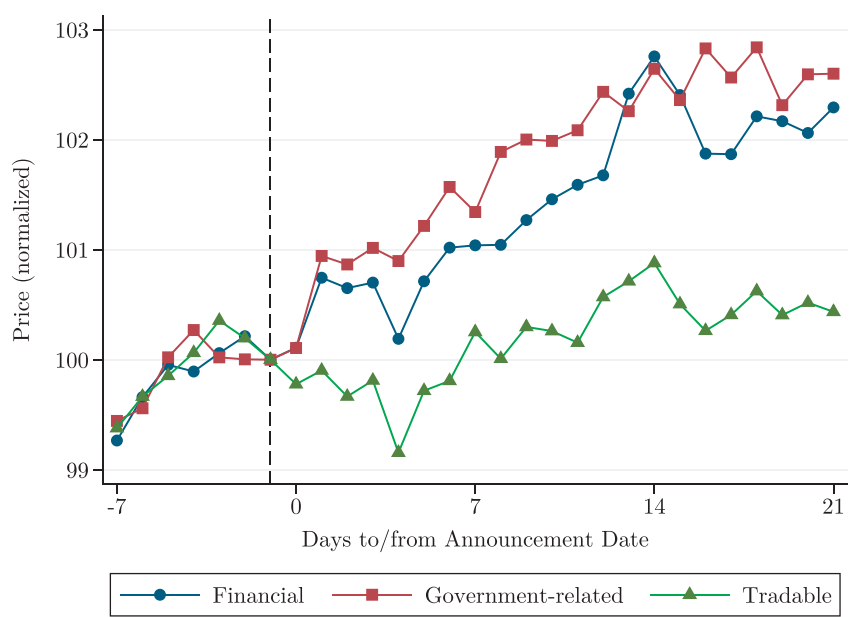

Fig. 1. Stock prices around events. Note: This figure depicts the evolution of the stock prices of financial firms, government-related firms, and firms operating in tradable sectors, separately, over a time window which starts 7 days before the announcement of each country's inclusion in the corresponding index, and ends 14 days after it. Stock prices are normalized to their values in the last trading day before each announcement episode, indicated by a vertical dashed line. Observations in the top and the bottom percentile of the country-by-date distribution of stock prices are excluded.

yield increase the CARs of financial and government-related firms by 1.7 percentage points. In addition, inflows that lead to a 1 percent appreciation of the exchange rate reduce the CARs of tradable firms by 0.41 percentage points. We conduct additional tests and robustness checks to support our empirical results. ${ }^{4}$

We present a stylized model of a small-open economy to rationalize our empirical findings. The economy contains tradable firms, non-tradable firms and banks. The tradable sector is capital intensive. Banks hold government debt and intermediate between domestic savers and borrowers. Crucially, there are no domestic financial frictions but there is limited borrowing from the international financial market. We model sovereign inflows as an increase in foreign purchases of government bonds, and show that they affect the economy through two channels. First, since the economy is constrained, they entail net capital inflows and thus reduce the domestic interest rate. This raises the price of government debt, which benefits banks directly, and expands domestic credit and thus the relative production of the tradable good. Among all firms, moreover, lower interest rates benefit especially those that are financially constrained, and - by reducing the cost of financing for the government - also those that are related to the public sector. Second, sovereign inflows raise the relative supply of tradables in the domestic economy, thereby appreciating the real exchange rate and benefitting the non-tradable sector. The model thus illustrates the basic forces at work behind our empirical estimates.

Our results are related to several broad strands of the literature. First, they contribute to the growing strand that focuses on the effects of financial flows on government bond yields and exchange rates in imperfectly integrated financial markets. For instance, Gabaix and Maggiori (2015) develops a model of exchange rate determination in which global investors' portfolio flows affect exchange rates because financiers have a limited capacity to absorb currency demand shocks. Hau (2014) develops a model where there is a common pool of risk-averse speculators so that shocks to the demand of one currency spill over to other currencies, and presents evidence consistent with this hypothesis. ${ }^{5}$ Our results relate closely to previous work that documents the importance of global investors in debt markets for sovereign yields and exchange rates (Du and Schreger, 2016; Pandolfi and Williams, 2019). ${ }^{6}$ More broadly, our study also speaks to the vast literature that focuses on the effects of demand shocks on sovereign yields in both emerging and developed economies. ${ }^{7}$

A second strand of literature related to our work analyses how changes in government bond yields and exchange rates affect firms. Our findings are consistent with previous studies that analyze empirically the effects of sovereign risk on domestic firms. ${ }^{8}$ They are also consistent with the view that the transmission of sovereign risk operates largely through the balance sheets of banks, and that it especially affects firms with large financing needs (Arellano et al., 2017). ${ }^{9}$ Additionally, our findings are related to numerous studies analyzing the effects of exchange rate movements on domestic firms. ${ }^{10}$

\footnotetext{
${ }^{4}$ For instance, to verify that the announcements reflect shocks that are specific to sovereign debt markets, we show that sovereign debt inflows increase sharply in announcement years while private inflows do not.

${ }^{5}$ Relatedly, Hau et al. (2010) shows that equity inflows in a given country are usually followed by an appreciation of the country's currency, and that other countries' currencies are affected by the inflows as well.

${ }^{6}$ Other studies which focus on the interactions between international investors' participation and the pricing of local currency sovereign bonds are those by Borri and Shakhnov (2018), Hofmann et al. (2019), and Morelli et al. (2019). Relatedly, Warnock and Warnock (2009) and Kohn (2015) analyze the effects of foreign purchases of U.S. government debt on U.S. sovereign bond yields.

7 Among others, Vayanos and Vila (2009), and Greenwood and Vayanos (2010) discuss the role of demand shocks from preferred-habitat investors in the determination of government bond yields. Recent studies focusing on the quantitative easing measures taken after the Global Financial Crisis also highlight that demand shocks and market segmentation can be important determinants of government bond yields (Krishnamurthy and Vissing-Jorgensen, 2011; Krishnamurthy et al., 2017).

${ }^{8}$ See, for instance, Hébert and Schreger (2017), Andrade and Chhaochharia (2018), and Chari et al. (2018).

${ }^{9}$ See Gennaioli et al. (2014) for a theoretical model of this transmission channel, and Altavilla et al. (2017) and Bottero et al. (2020) for related evidence.

10 Although the conventional view is that depreciations improve a country's competitiveness and favor tradable industries (Gabaix and Maggiori, 2015), this view has been recently questioned on the grounds that export prices are sticky in a dominant currency (Gopinath et al., 2020).
} 
Furthermore, this paper also relates to a vast international macroeconomics literature that studies the effects of capital flows on firms, but it has mostly focused on FDI, bank, and equity portfolio flows. ${ }^{11}$ A study that is closely related to ours is Blanchard et al. (2017), which argues that, while equity inflows to emerging economies should be expansionary, bond inflows might be contractionary. We show that the effect of sovereign debt inflows differs across sectors, in line with the evidence in Benigno et al. (2015) that episodes of large inflows are followed by a reallocation of labor and investment from tradable to non-tradable sectors. Also, related to ours is the study by Kolasa and Wesolowski (2020), which develops a two-country open-economy model with segmented markets and shows that quantitative easing in developed countries can induce sovereign debt inflows in emerging countries which boost domestic demand but dampen international competitiveness.

Our results are also related to studies that analyze the effects of equity market liberalizations and equity index rebalancing on asset prices. This work focuses on how equity inflows affect the discount rate used to price risky assets. Our perspective is different because we focus on sovereign debt inflows and also consider their effects on firms' cash flows. In Section 5, we discuss in greater detail the relationship to these studies and the implications for the interpretation of our results. ${ }^{12}$

The rest of the paper is structured as follows. Section 2 presents the empirical setting, describing the testable implications that we bring to data, the announcement episodes, and the data used to conduct the analysis. Section 3 presents the first set of results on sovereign bond yields and exchange rates. Section 4 presents the main results on the stock market effects of sovereign debt inflow shocks on domestic firms. Section 5 discusses the potential determinants of the heterogenous cross-country reaction in response to the announcement episodes, the role of expected and actual inflows, and the drivers of the stock market effects. Section 6 presents a model that rationalizes our empirical findings. Finally, Section 7 concludes.

\section{Empirical setting}

In the textbook small, open economy model without frictions, shocks to foreigners' demand for local currency sovereign debt should have no impact on the domestic economy. In a nutshell, the gross inflows entailed by foreigners' demand for domestic debt would be compensated one-for-one by a reduction of other gross inflows or by an increase of gross outflows. In the presence of financial frictions, however, this is not true.

First, financial frictions may hamper access to international financial markets. In this case, sovereign inflows increase the availability of financial resources and lead to a reduction in government yields and other domestic interest rates. In other words, sovereign inflows reduce the government's reliance on domestic financial markets and free up resources for the private sector (Becker and Ivashina, 2018; Ongena et al., 2019; Williams, 2018). ${ }^{13}$ In this way, they foster private investment and fuel the expansion of firms and sectors that rely heavily on external finance (Arellano et al., 2017). Moreover, through their effect on the price of public debt, sovereign inflows provide an windfall for bondholders, in particular domestic financial institutions (Gennaioli et al., 2014). We will test for these implications in the data by empirically analyzing the effects of sovereign inflows on domestic financial firms, on firms that are more financially constrained, and on firms that are connected to the government. (Chari et al., 2018).

Second, by increasing the relative availability of tradable goods, sovereign debt inflows should lead to an appreciation of the exchange rate. This appreciation should in principle hurt, in relative terms, firms in the tradable sector (Gabaix and Maggiori, 2015).

In this paper, we analyze the effects of exogenous shocks to the foreign demand for local currency sovereign debt on the stock returns of: (i) domestic financial firms, (ii) firms that are connected to the government, (iii) firms that are more financially dependent, and (iv) tradable firms. The conceptual discussion above suggests that, to the extent that sovereign inflows relax domestic financial conditions, (i), (ii), and (iii) should be positive. In addition, to the extent that sovereign inflows lead to an appreciation of the exchange rate, (iv) should be negative. In Section 6, we present a stylized model that formalizes this conceptual discussion.

\subsection{Index inclusions as sovereign debt inflow shocks}

To analyze the consequences of sovereign debt inflows for domestic firms, we exploit episodes of country inclusion in two major global, local-currency sovereign debt indexes that are widely used as benchmarks by international investors: the Citigroup WGBI and the JP Morgan GBI-EM. ${ }^{14}$ Specifically, we exploit the inclusions in the GBI-EM of local-currency bonds issued by the governments of Colombia, Czech Republic, Nigeria, and Romania, and the inclusions in the WGBI of local-currency bonds issued by the governments of Mexico and South Africa. ${ }^{15}$ These inclusions were announced by index providers on specific dates which we retrieved from their websites. ${ }^{16}$

\footnotetext{
11 See among others Schnabl (2012), Alfaro et al. (2014), Lane and McQuade (2014), Baskaya et al. (2017), Calomiris et al. (2020), Sander (2019). This literature has analyzed the effects of capital account liberalizations on firms' stock market value (see Chari and Henry (2004), Chari and Blair Henry (2008) and Larrain (2015).

12 See Henry (2000) for an analysis of the heterogenous stock-price effects of equity market liberalizations, and Greenwood (2005) and Hau (2011) for an analysis of the effects of equity index redefinitions on asset prices.

13 In other words, foreign purchases of public debt reduce its “crowding-out" effect thereby raising private investment (see Broner et al. 2014, Broner et al. 2019, and Priftis and Zimic 2020).

${ }^{14}$ For more details on how these indexes are created and their importance see Section A.1 in the Appendix.

15 We do not consider inclusions into foreign currency sovereign debt indexes. The reason is that inclusion into these indexes, such as the J.P. Morgan EMBI Global Diversified, happens automatically when a country issues bonds that comply with the index criteria (size, maturity, currency of denomination, and daily price availability). In fact, there is only one episode that is similar to the ones studied in this paper, i.e., the 2019 inclusion of 5 Gulf Cooperation Council countries into the EMBI that followed a change in J.P. Morgan's definition of emerging countries.

${ }^{16}$ In particular, the first trading days after the announcement episodes are the $19^{\text {th }}$ of March 2014 (Colombia), the $22^{\text {nd }}$ of February 2017 (Czech Republic), $31^{\text {st }}$ of March 2010 (Mexico) the $16^{\text {th }}$ of August 2012 (Nigeria), the $16^{\text {th }}$ of January 2013 (Romania), and the $17^{\text {th }}$ of April 2012 (South Africa). For Nigeria, the announcement date is somewhat ambiguous because it is not clear whether the news were released on the 14th or the 15th of August 2012. For the Czech Republic, the implications of the announcement for the size of inflows are somewhat ambiguous because the country's inclusion into the index implied its exclusion from another index. We provide more details about all inclusion announcements in Section A.2 in the Appendix.
} 
These events constitute an ideal laboratory to address our research question because they trigger large sovereign debt inflows. International investors who are benchmarked against each index have incentives to rebalance their portfolios, purchasing sovereign bonds of the newly included country to replicate the index composition. ${ }^{17}$ Even though the inclusion is usually implemented gradually by index providers over the 3 to 12 months following the announcement, investors have incentives to start rebalancing their portfolios gradually at the announcement date in order to minimize rebalancing costs. Fig. 2 depicts the evolution of the average share of sovereign debt held by private foreign investors across 4 of the 6 countries in our sample around the corresponding announcement dates. ${ }^{18}$ The figure clearly shows that, already in the quarter of the announcement, foreign holdings of these countries' sovereign debt increases sharply and deviates from the pre-announcement trend.

To grasp the magnitude of these inclusion-driven shocks, we follow Pandolfi and Williams (2019) and adapt their Flows Implied by Rebalancings (FIR) measure to our setting. We compute the estimated inflow shocks as the change in the benchmark weight of each country - calculated over the entire implementation period - multiplied by the value of assets managed by funds that track their returns against the corresponding benchmark index, normalized by the market value of the sovereign debt securities that are incorporated to the index. The FIR measure captures the total inflows that would enter the country if all funds that track the index were to replicate its composition. The estimated FIR for the episodes we consider is $18 \%$ in Colombia, 25\% in Czech Republic, 12\% in Mexico, 31\% in Nigeria, 30\% in Romania, and 10\% in South Africa. Hence, the estimated sovereign debt inflows are large relative to the market capitalization of the securities included in the index.

Additionally, these events share two features which are key for our identification strategy. First, inclusion announcements are unanticipated. The inclusions themselves are unlikely to come fully as a surprise, as in some cases markets may have expected these countries to be included in the index at some point. However, the exact timing of the inclusion is not anticipated by investors. ${ }^{19}$ Second, the announcements are not contemporaneous with macroeconomic shocks which might have a direct effect on stock prices. ${ }^{20}$ One indication of this is that announcements are not followed by inflows into the private sector, as shown in Fig. 3. The Figure depicts average public and private inflows in the three years before the announcement and in the year of the inclusion event. It shows that inclusions trigger large inflows that are specific to the sovereign debt markets of newly included countries. In particular, public inflows in the year of the inclusion are on average three times higher than they were in the three years prior to the announcement. Instead, private inflows remain almost unchanged. ${ }^{21}$

\subsection{Data}

Our data covers Colombia, Czech Republic, Mexico, Nigeria, Romania, and South Africa, and is collected from several sources. The daily time series of local currency 5-year government bond yields and prices comes from Bloomberg, and the daily time series of (end-of-day) exchange rates against the US Dollar comes from Datastream.

At the firm level, the time series of daily (end-of-day) stock prices of domestic public companies and additional information such as the International Securities Identification Number (ISIN), the industry classification, and a concise description of each firm's business activity all come from Datastream. So does the daily time series of returns on the MSCI Emerging Markets Index and the MSCI World Index, which we use to compute abnormal returns. End-of-year balance sheet data come from Worldscope.

To identify firms that are closely related to the government, we proceed in two steps. First, from Thomson Reuters Securities Data Company (SDC) Platinum we retrieve the list of firms whose major shareholder is the state. Second, we perform a search in the business description of firms and look for the words government or public. We use this information to construct the indicator variable $\mathbb{1}$ (Govt), which equals one if a company is partially owned by the government or its business activity is related to the government. To identify financial and tradable firms, we follow the industry classification in Datastream. Specifically, the indicator variable $\mathbb{1}$ (Financial) takes the value 1 if a firm is classified as a bank, a financial firm, an investment firm, or a life insurance company. The indicator variable $\mathbb{1}$ (Tradable) takes the value 1 if a firm operates in a tradable industry according to the classification scheme in Mian and Sufi (2014). ${ }^{22}$ To measure financial dependence, we follow Rajan and Zingales (1998) and use Worldscope data to compute the ratio of capital expenditures net of cash flows from operations to capital expenditures. We use the median of this measure in each industry as a proxy for financial dependence, denoted EFD.

To identify firms that have access to corporate debt markets, we retrieve from Thomson Reuters SDC Platinum the list of companies that issue corporate bonds or have syndicated loans at any time before the announcement. We match firms in this list to firms in our database using the SEDOL and generate the dummy variable $\mathbb{1}$ (DebtIssuer), which equals 1 in case of a successful merge. Finally, we merge the list of firms in our sample with the list of companies that are included in the MSCI Emerging Markets index. Since stocks of these companies are more likely to be held by foreigners, we use this information to create the

\footnotetext{
17 Evidence of international investors' tendency to replicate the composition of the indexes they track is abundant in the literature. See for instance Cremers et al. (2016) and Raddatz et al. (2017) for evidence, and Basak and Pavlova (2013) and Kashyap et al. (2018) for a theoretical justification of this behavior.

18 The data used to produce this figure is from Arslanalp and Tsuda (2014) and do not include information of foreign private holdings of Czech and Nigerian debt.

19 Consistent with the unexpected nature of the shock, we show in Section 3 that 5-year government bond yields in all newly included countries drop significantly on the exact dates in which inclusions are announced.

20 This is why the inclusion of Argentina in the GBI-EM, which coincided with the removal of capital controls, is not part of our sample.

21 Figure A1 in the Appendix reports the evolution of private and public inflows around the announcement year for each of the countries in our sample, separately.

22 In particular, we follow the first classification scheme in Mian and Sufi (2014), according to which an industry is tradable if the sum of its exports and imports exceeds 10,000 U.S. dollars per worker or 500 million U.S. dollars in total.
} 


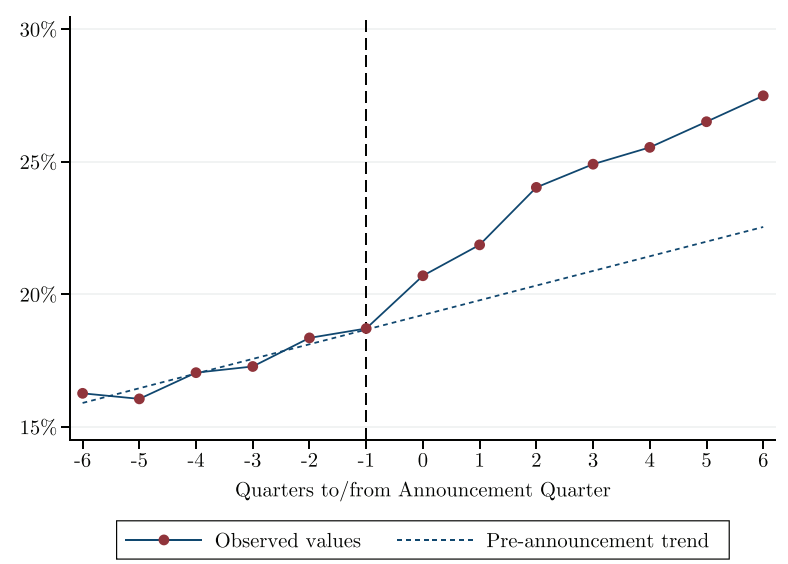

Average Private Foreign Share of Government Debt

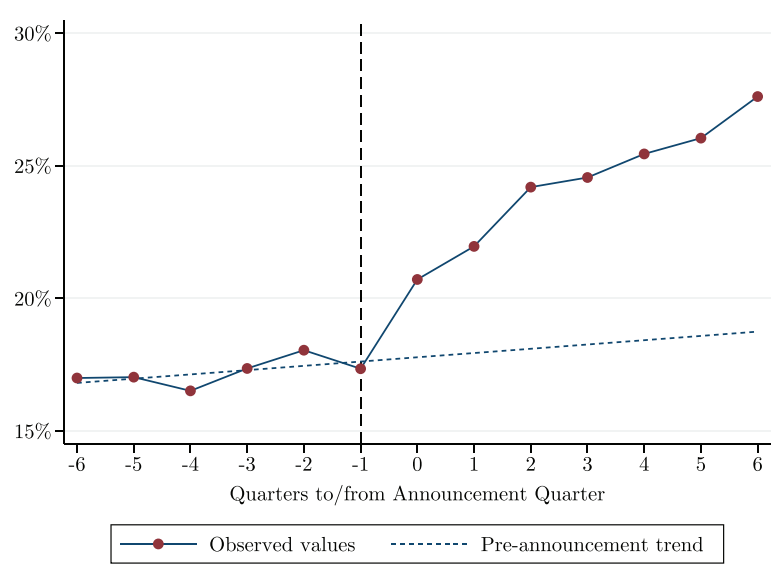

Median Private Foreign Share of Government Debt

Fig. 2. Foreign share of sovereign debt around events. This figure depicts the quarterly time series of the average and the median (left panel and right panel, respectively) share of sovereign debt held by foreign private investors for Colombia, Mexico, Romania and South Africa over a time window which starts 6 quarters before the announcement of each country's inclusion in the corresponding index, and ends 6 quarters after it. In both panels, the dotted line is a linear trend estimated on the pre-announcement period. The vertical dashed line indicates the quarter prior to the announcement episodes. Data is from Arslanalp and Tsuda (2014).

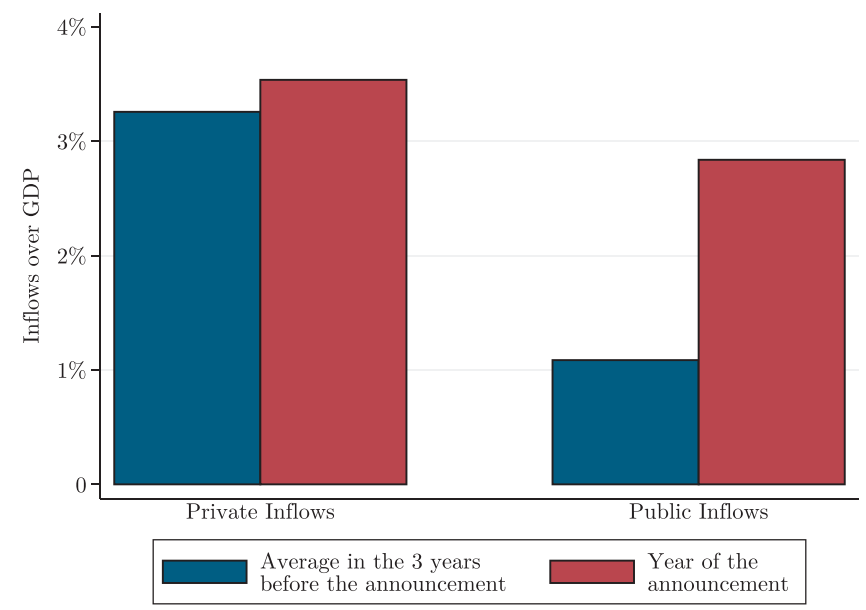

Fig. 3. Balance of payments: private vs. public inflows. This figure depicts the average private and public net inflows to Colombia, Czech Republic, Mexico, Nigeria, Romania and South Africa in the year of the announcement of each country's inclusion into the corresponding index vs. the average of public and private inflows to these countries in the three years before the announcement episodes. Private inflows are the sum of foreign direct investments, portfolio equity net inflows and private debt net inflows. Public inflows are net inflows to the countries' sovereign debt markets. Both are in U.S. dollars and are normalized by the GDP of each country, before being averaged across countries. Data is from the IMF Balance of Payments Statistics and IMF WEO.

indicator variable $\mathbb{1}$ (ForOwnership), which is equal to 1 if a company is included in this equity index in the quarter preceding the shock.

Table 1 reports summary statistics of firms in our sample. The table reports the share of financial firms, government-related firms, and tradable firms (on the announcement date) in the entire sample and in each country separately. In the entire sample, $35 \%$ of firms are tradable, $14 \%$ are financial, and $9 \%$ are government-related. The country with the highest share of financial firms is Colombia (36\%), the one with the highest share of government-related firms is Czech Republic (36\%), and the one with the highest share of tradable firms is Romania (54\%). All countries have firms in the MSCI Emerging Markets index, as well as firms issuing corporate bonds or syndicated loans. In total, our sample is composed of 909 companies, where the least represented country is Czech Republic (14 companies) and the most represented country is South Africa ( 361 companies). ${ }^{23}$

\footnotetext{
${ }^{23}$ In our sample, we consider each security as a distinct company. Actually, 28 companies appear twice in our dataset, as each of them issue two distinct types of securities. In the Appendix, we show that reducing each of these companies to a single observation does not change the results of our analysis.
} 


\section{Sovereign debt inflows, exchange rates, and sovereign bond yields}

According to our hypotheses, sovereign debt inflows can have a substantial impact on the economies of recipient countries through their effect on sovereign bond yields and exchange rates. We thus begin our empirical analysis by assessing the response of these two variables to the country-inclusion announcement episodes in our sample.

First, in Fig. 4, we depict the daily time series of each country's local-currency, 5-year government bond yield in the 2 years around the announcement episode. The figure shows that government yields drop sharply when index providers announce the inclusion of countries into their benchmark indexes. Further, the figure shows that there are no common pre-announcement trends in government bond yields across countries, thus supporting our identifying assumption that announcement dates were unexpected.

Fig. 5 reports the daily time series of each country's exchange rate in the 2 years around the announcement episodes. The exchange rate is defined in terms of units of domestic currency per US dollar, and is normalized to its value in the last trading day before the announcement. In all countries, the exchange rate appreciates on the announcement date. Moreover, there is no pre-announcement trend that is common to all countries. The appreciation on the date of the announcement is not as sharp as the drop in the yields, which may be due to the higher volatility of exchange rates relative to sovereign bond yields.

To assess the economic magnitude of these two effects in each country, we compare the 2-day changes in the sovereign bond yield and in the exchange rate after the announcement with the distribution of 2-day changes in a 2 year-window around the announcement. Figs. 6 and 7 provide a graphical representation of this comparison. In most cases, the 2-day change after the announcement lies in the very left tail of the distribution, representing an outlier observation. In all countries, as reported in Table 2 , the 2-day change in both the government bond yield and the exchange rate after the announcement is statistically different from the average 2-day change. The table also reports the post-announcement changes for all countries, which range from 4.8 (Mexico) to 90 (Romania) basis points for sovereign yields and from 0.057 (Nigeria) to 2 (Colombia and Romania) percentage points for the exchange rate.

These findings are broadly in line with those of previous work that studies the price effects of index inclusions. Most of these studies focus on U.S. equity indexes, and find an average price increase of around $3.5 \% .{ }^{24}$ In emerging asset markets, index inclusions are found to have smaller effects on prices, of about 2\% (Hacibedel and van Bommel, 2007). In our data, the effect of inclusion on the price of sovereign bonds is of a similar magnitude, of about $1.1 \%$ in the 2 days and $2.5 \%$ in the 2 weeks following the announcement (see Fig. 8).

\section{The effects of sovereign debt inflows on domestic firms: an event study}

To measure the effect of sovereign debt inflow shocks on domestic firms, we conduct a multiple event study around the dates in which country inclusions are announced by index providers. Specifically, we calculate the cumulative abnormal returns of domestic listed firms in the two trading days following the announcements - which should reflect changes in firms' future prospects - and use them to test the empirical predictions discussed in Section 2.

We compute abnormal returns for listed domestic firms in four ways. First, we calculate daily abnormal returns for each firm as the difference between the return in each trading day and the average daily return in 252-trading-day window that ends 10 days before each country's announcement date. We then cumulate these abnormal returns over the first two trading days after the announcements and define the resulting CAR as CAR ${ }_{i}^{\text {Demeaned }}$. Second, we compute each firms' daily abnormal returns as the difference between the actual returns and the returns predicted by a 1-factor model where the only risk factor is the daily return of the MSCI EM Index. ${ }^{25}$ We label the 2-day CAR thus calculated as CAR ${ }_{i}^{1-F a c t o r}$. Third, we calculate daily abnormal returns as the difference between the actual returns and the returns predicted by a 2-factor model which, on top of the regional factor, includes also a global factor, i.e., the daily return of the MSCI World Index. Cumulating these abnormal

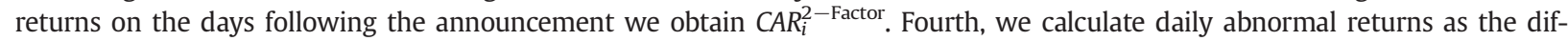
ference between the actual returns and the returns predicted by a 5-factor model which adds to the regional and global factors, a small-minus-big (SMB), high-minus-low (HML), and momentum (WML) factors, which we use to calculate $C A R_{i}^{5-F a c t o r}{ }^{26}$ In our baseline specification we use 2-day CARs calculated with these four alternative models as our main dependent variables. $^{27}$

\footnotetext{
${ }^{24}$ Among the first to examine the effects of stock inclusions into the S\&P500, Shleifer (1986) and Harris and Gurel (1986) find price increases of 2.8\% and 3.1\%, respectively. More recently, Chen et al. (2004) find a price increase between 3.2\% and 5.4\% while Patel and Welch (2017) estimate it to be around 3.5\%.

25 We do not use domestic stock market indexes to compute predicted returns since, in some of the countries in our sample, these indexes are composed of a few large firms (often financial firms), whose returns have a major impact on the performance of the index.

${ }^{26}$ Factor loadings of all factor models are estimated by running a series of firm-specific regressions over the 252-day window specified above. To compute the SMB, HML, and WML factors we follow Cakici et al. (2013) and compute them using stock market data from all countries in the sample.

27 We use the 2-day CARs in our baseline specification following the literature (e.g. Alfaro et al. (2017)), but we show in the Appendix (Figure A2) that our results are robust to using 3-, 4-, and 5-day CARs. We exclude observations in the top and bottom percentiles of the country-specific distribution of 2-day CARs, to control for outlier observations.
} 
Table 1

Summary statistics.

\begin{tabular}{lllllllll}
\hline & Mean & St. Dev. & CO & CZ & MX & NG & RO & ZA \\
\hline Financial & 0.14 & 0.35 & 0.36 & 0.21 & 0.14 & 0.17 & 0.10 & 0.10 \\
Government-Related & 0.09 & 0.29 & 0.19 & 0.36 & 0.07 & 0.11 & 0.05 \\
Tradable & 0.35 & 0.48 & 0.19 & 0.21 & 0.23 & 0.42 & 0.54 \\
External Financial Dependance & -2.04 & 2.91 & -2.53 & -1.88 & -2.04 & -2.19 & -1.65 & 0.32 \\
Foreign Ownership & 0.11 & 0.31 & 0.18 & 0.21 & 0.16 & 0.09 & 0.02 & 0.12 \\
Issue Debt & 0.16 & 0.36 & 0.38 & 0.36 & 0.47 & 0.04 & 0.05 \\
Log(Assets) & 15.44 & 3.25 & 21.68 & 16.57 & 16.43 & 17.41 & 12.18 \\
\hline Observations & \multicolumn{2}{c}{909} & & 72 & 14 & 137 & 170 & 14.33 \\
\hline
\end{tabular}

This table reports summary statistics about domestic firms in our sample. The first two columns report the mean and the standard deviation of our main explanatory variables computed over the entire sample of firms. Columns 3 to 8 report the average of these variables in each of the countries in our sample (Colombia, Czech Republic, Mexico, Nigeria, Romania, and South Africa). Financial is an indicator variable that is equal to 1 for financial firms. Government-Related is an indicator variable that is equal to 1 for government-related firms. Tradable is an indicator variable that is equal to 1 for firms in tradable industries (according to the classification in Mian and Sufi (2014)). External Financial Dependance is a measure of firms' dependance on external financing sources, computed following Rajan and Zingales (1998). Foreign Ownership is an indicator variable that is equal to 1 for firms which are included in the MSCI Emerging Markets Index in the year prior to the announcement date. Issue Debt is an indicator variable that is equal to 1 for firms that issued corporate debt or obtained a syndicated loan in the years before the announcement date.
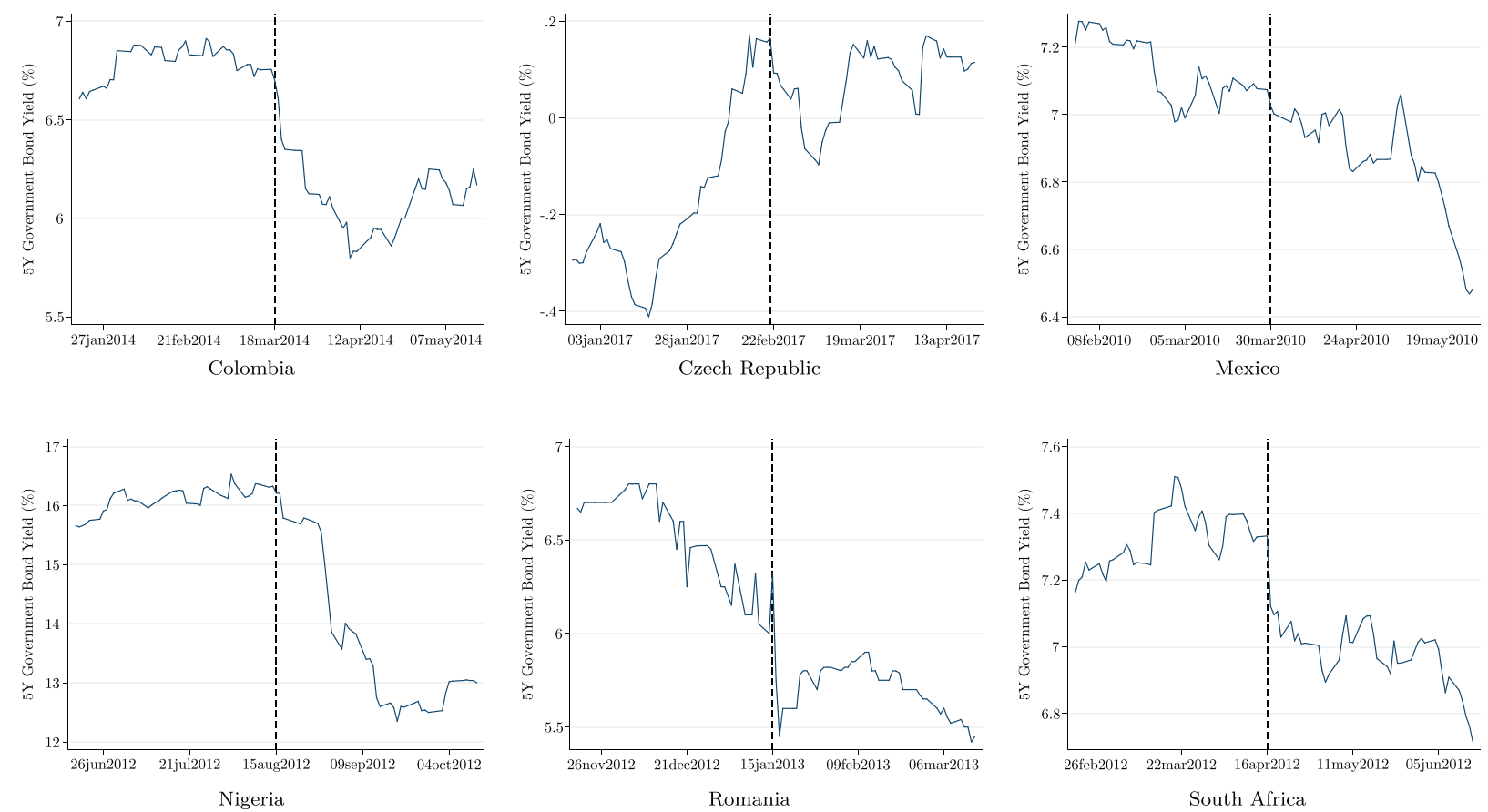

Fig. 4. 5-Year government bond yields around events. This figure depicts the time series of the 5-year local currency government bond yield in Colombia, Czech Republic, Mexico, Nigeria, Romania and South Africa over a time window which starts 2 months before the announcement of each country's inclusion in the corresponding index, and ends 2 months after it. The vertical dashed line indicates the last trading day before each announcement episode.

\subsection{Effects of sovereign debt inflows}

We start our empirical analysis by looking at the overall effects of the announcements and the associated sovereign debt inflows on domestic firms. To this end, we calculate the average CAR of all firms in our sample in the two days following the announcement dates as:

$$
\overline{C A R}^{j}=\frac{\sum_{i}^{I} C A R_{i}^{j}}{I}
$$




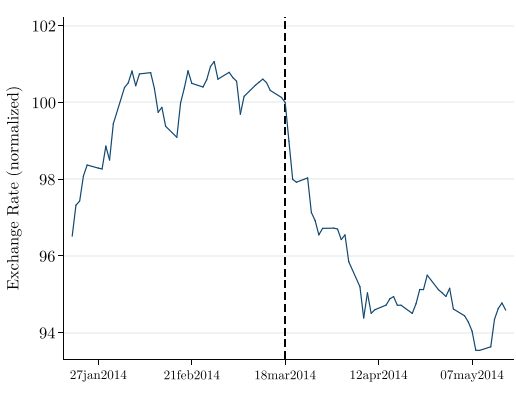

Colombia

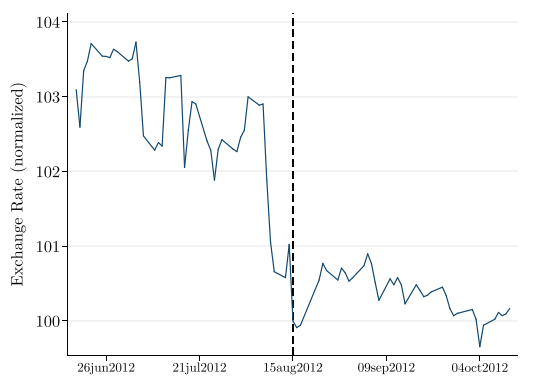

Nigeria

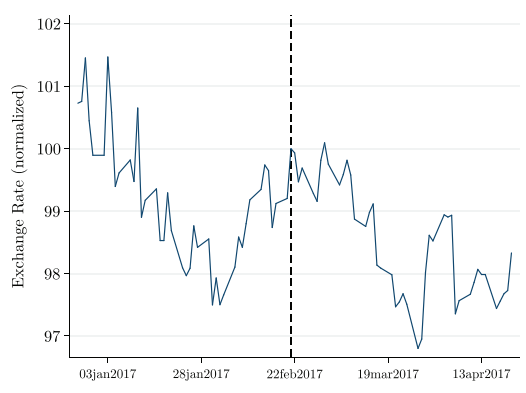

Czech Republic

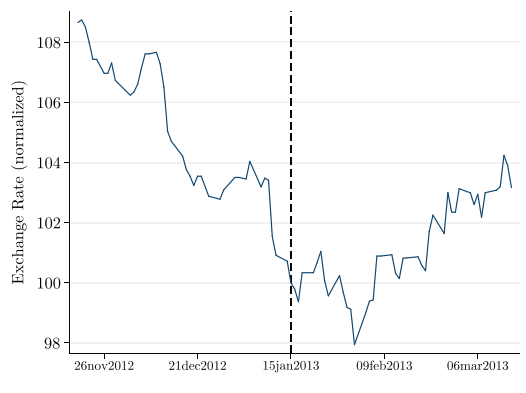

Romania

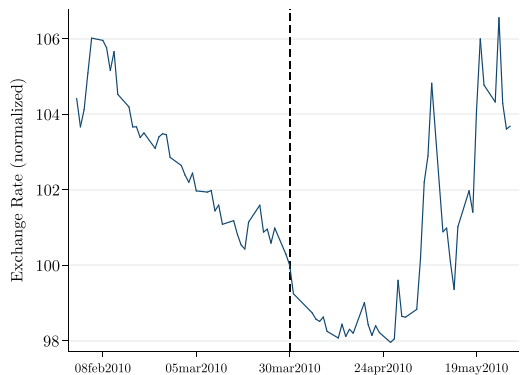

Mexico

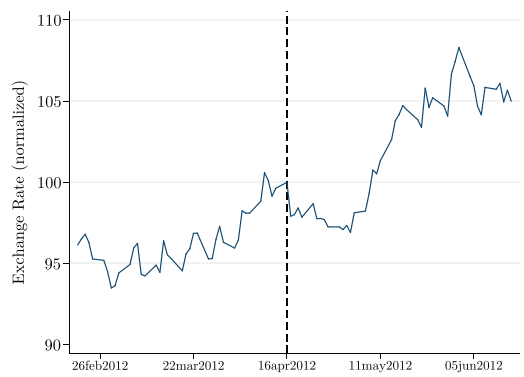

South Africa

Fig. 5. Exchange rates around events. This figure depicts the time series of the exchange rate in Colombia, Czech Republic, Mexico, Nigeria, Romania and South Africa over a time window which starts 2 months before the announcement of each country's inclusion in the corresponding index, and ends 2 months after it The exchange rate for each country is the amount of local currency needed to buy 1 U.S. dollar, and is normalized to its value in the last trading day before each announcement episode, indicated by a vertical dashed line.

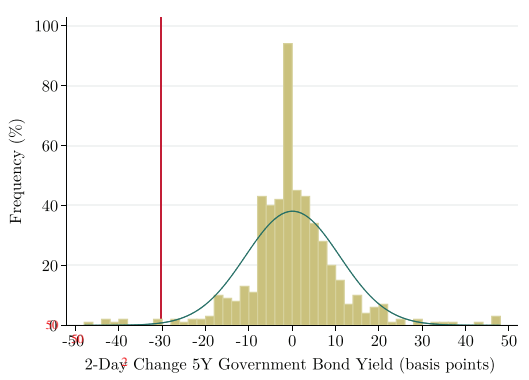

Colombia

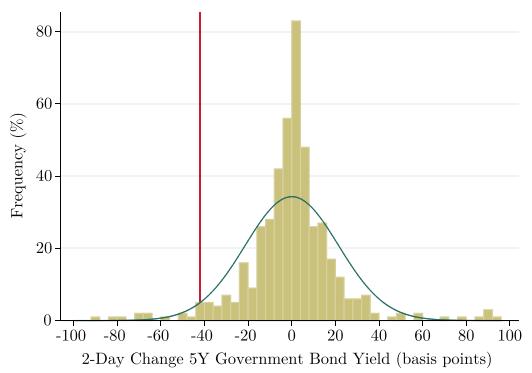

Nigeria

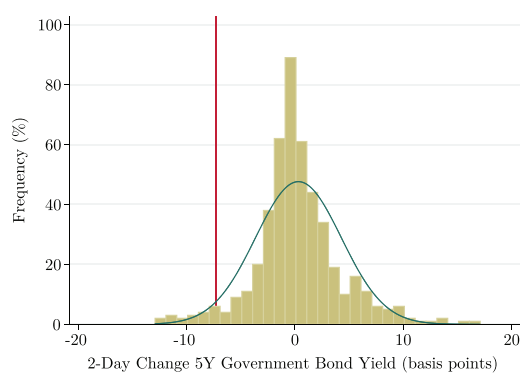

Czech Republic

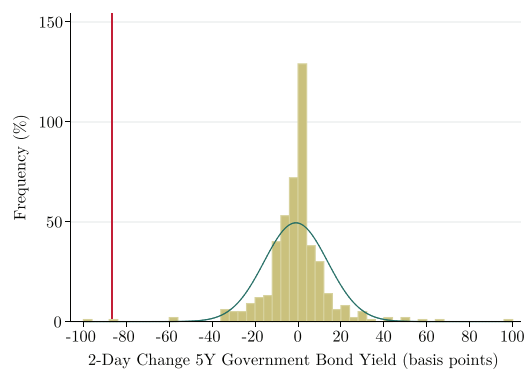

Romania

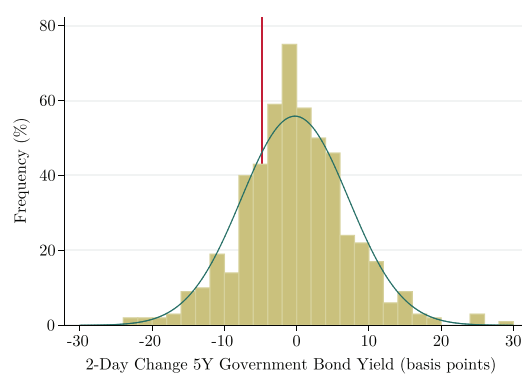

Mexico

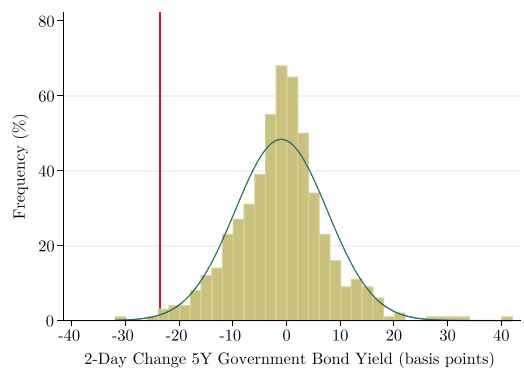

South Africa

Fig. 6. Distribution of 2-day Changes in 5Y Government Bond Yields. This figure depicts the distribution of 2-day changes in the 5-year local currency government bond yield in Colombia, Czech Republic, Mexico, Nigeria, Romania and South Africa in the 2 years around the announcement of each country's inclusion in the corresponding index. The vertical line in each panel indicates the change in the 5-year government bond yield in the 2 days following the announcement episode in each country. 


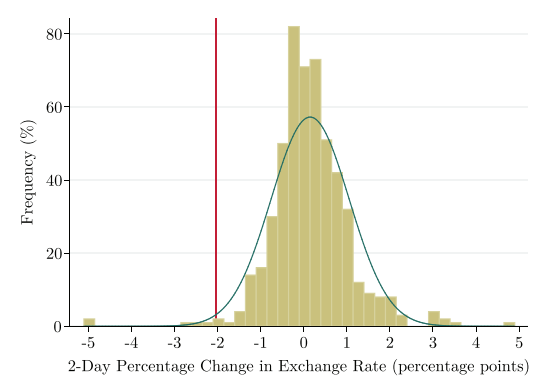

Colombia

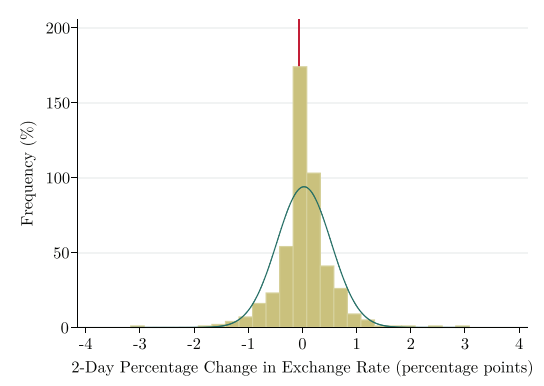

Nigeria

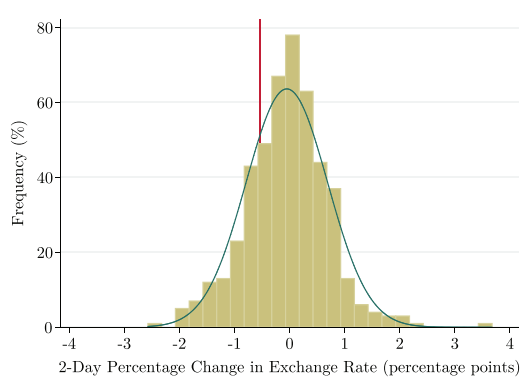

Czech Republic

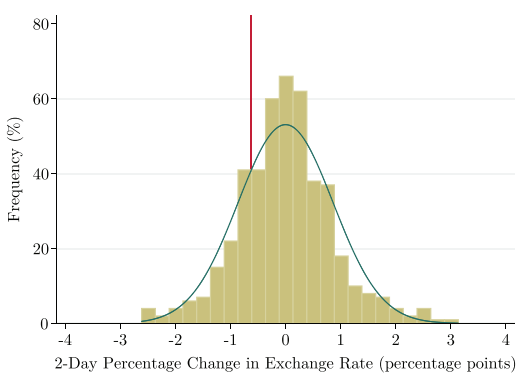

Romania

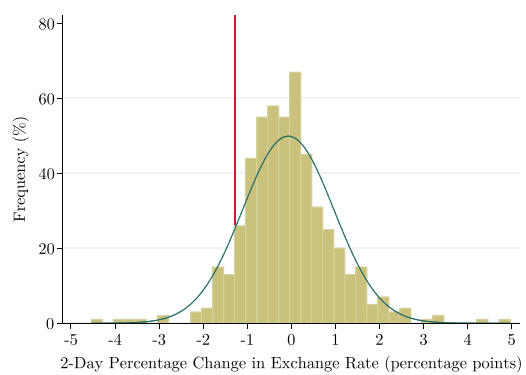

Mexico

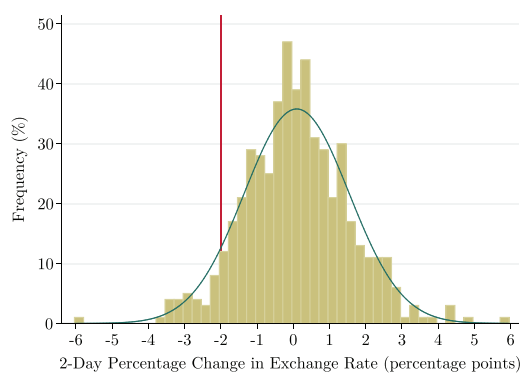

South Africa

Fig. 7. Distribution of 2-day Percentage Changes in Exchange Rates. This figure depicts the distribution of 2-day changes in the log of the exchange rate in Colombia, Czech Republic, Mexico, Nigeria, Romania and South Africa in the 2 years around the announcement of each country's inclusion in the corresponding index. The vertical line in each panel indicates the percentage change in the exchange rate in the 2 days following the announcement episode in each country.

Table 2

Shocks.

\begin{tabular}{|c|c|c|c|c|c|c|}
\hline & Colombia & Czech Rep. & Mexico & Nigeria & Romania & South Africa \\
\hline$\Delta$ Yield (bps) & -30.190 & -7.300 & -4.800 & -42.000 & -86.900 & -23.600 \\
\hline$\Delta$ Yield- $\overline{\Delta \text { Yield }}$ & $-30.649^{* * *}$ & $-7.641^{* * *}$ & $-4.569^{* * *}$ & $-42.870^{* * *}$ & $-85.819^{* * *}$ & $-22.674^{* * *}$ \\
\hline$\% \Delta \operatorname{ExchRate}(\mathrm{pp})$ & -2.026 & -0.532 & -1.266 & -0.057 & -0.633 & -2.006 \\
\hline$\% \Delta$ ExchRate $-\% \Delta$ ExchRate & $-2.179^{* * *}$ & $-0.484^{* * *}$ & $-1.200^{* * *}$ & $-0.077^{* * *}$ & $-0.635^{* * *}$ & $-2.120^{* * *}$ \\
\hline
\end{tabular}

This table reports the changes in government bond yields and exchange rates in the 2 days following the announcement of each country's inclusion in the corresponding index. $\Delta$ Yield(bps) is the 2-day change in the 5-year local currency government bond yield in basis points. \% $\Delta$ ExchRate(pp) is the 2-day percentage change in the exchange rate (computed as the difference in the log of the exchange rate) in percentage points. $\Delta$ Yield $-\overline{\Delta \text { Yield }}$ and $\% \Delta$ ExchRate $\overline{\% \Delta \text { ExchRate }}$ are the differences between the changes in government bond yields and exchange rates in the 2 days following the announcement episodes, and the average 2-day changes of these two variables in the 2 years around the announcement of each country's inclusion in the corresponding index. *, **, ***, denote that these differences are statistically different from 0 at the $10 \%, 5 \%$, and $1 \%$ confidence level, respectively.

where I the total number of observations and $C A R_{i}^{j}$ is the 2-day CAR of firm $i$ calculated using model $j$.

Table 3, Panel A, reports the average post-announcement 2-day CARs of domestic listed firms in our sample. On average, the CARs are positive and they range between 0.11 and 0.22 percentage points, depending on the way abnormal returns are calculated. Only the average CARs computed with the first model (the demeaned returns) are statistically different from zero. Panel $\mathrm{B}$ of Table 3 reports the average CARs before the announcement date, calculated over the interval [t-3,t-2], where $t$ is the first trading day after the announcement. None of these pre-announcement CARs is statistically different from zero. The evidence in Panel B is consistent with the hypothesis that announcement dates are not anticipated by investors. This evidence refers to average CARs, however, and masks important heterogeneity across firms.

\subsection{Heterogeneous effects}

As discussed in Section 2, sovereign debt inflows can have heterogenous effects on different industries. In particular, financial and government-related firms can be expected to benefit most from inflows, while tradable firms can be hurt by them. Hence, the weak effects of anouncemenets documented above may conceal strong effects at the industry level. 


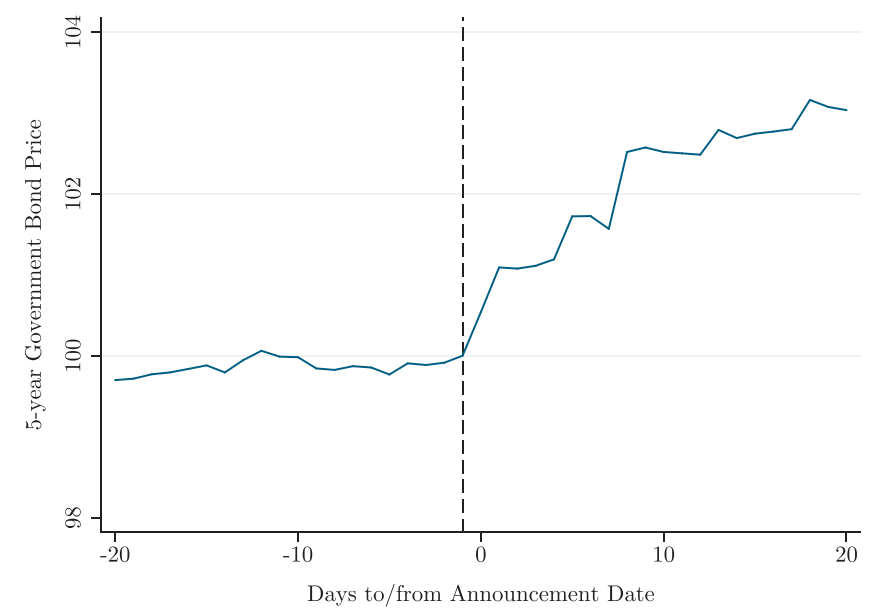

Fig. 8. 5-Year Government Bond Prices around Events. This figure depicts the time series of the average 5-year local currency government bond prices across Colombia, Czech Republic, Mexico, Nigeria, Romania and South Africa over a time window which starts 20 trading days before the announcement of each country's inclusion in the corresponding index, and ends 20 trading days after it. The index (which is equal to 100 in the day before the announcement for each country) is constructed by taking the average change in log prices across countries. The vertical dashed line indicates the last trading day before each announcement episode.

Table 3

Aggregate cumulative abnormal returns.

\begin{tabular}{|c|c|c|c|c|}
\hline \multicolumn{5}{|c|}{ Panel A: Cumulative abnormal returns after announcement Dates } \\
\hline & Demeaned returns & 1-Factor model & 2-Factor model & 5-Factor model \\
\hline Average 2-day CAR & $\begin{array}{l}0.219^{* *} \\
(0.099)\end{array}$ & $\begin{array}{l}0.133 \\
(0.102)\end{array}$ & $\begin{array}{l}0.111 \\
(0.102)\end{array}$ & $\begin{array}{l}0.117 \\
(0.108)\end{array}$ \\
\hline Number of Countries & 6 & 6 & 6 & 6 \\
\hline Observations & 861 & 861 & 861 & 861 \\
\hline \multicolumn{5}{|c|}{ Panel B: Cumulative abnormal returns before announcement dates } \\
\hline & Demeaned returns & 1-Factor model & 2-Factor model & 5-Factor model \\
\hline Average 2-day CAR & $\begin{array}{l}0.117 \\
(0.096)\end{array}$ & $\begin{array}{l}0.014 \\
(0.096)\end{array}$ & $\begin{array}{l}0.041 \\
(0.096)\end{array}$ & $\begin{array}{l}-0.006 \\
(0.097)\end{array}$ \\
\hline Number of Countries & 6 & 6 & 6 & 6 \\
\hline Observations & 861 & 861 & 861 & 861 \\
\hline
\end{tabular}

This table reports the average cumulative abnormal return of firms in our sample after and before the announcement of each country's inclusion in the corresponding index (Panel A and Panel B, respectively). The average CAR in Panel A is computed as the average CAR in the 2 days following the announcement. The average CAR in Panel B is computed as the average CAR over the interval [ $t-3, t-2]$, where $t$ is the first trading day after the announcement. CARs in the first column (the demeaned returns) are computed as the cumulated differences between the daily returns and the average daily return in the year preceding the announcement. CARs in columns 2 to 4 are computed using three different factor models. The only risk factor in the 1 -factor model is the return of the MSCI Emerging Markets Index; the two risk factors in the 2-factor model are the return of the MSCI Emerging Markets Index and the return of the MSCI World Index; the 5-factor model include these two risk factors plus small minus big (SMB), high minus low (HML), and momentum (WML) factors. Observations in the top and the bottom percentile of the country-specific distribution of 2-day cumulative abnormal returns are excluded. Standard errors in parenthesis are clustered at the country-byindustry level. *, ${ }^{* *},{ }^{* * *}$, denote that the the average CAR is statistically different from 0 at the $10 \%, 5 \%$, and $1 \%$ confidence level, respectively.

Fig. 9 provides evidence that this is indeed the case. It depicts the abnormal returns - cumulated on the interval that starts 3 trading days before the announcement date in each country and ends 5 days after it - for all firms in our sample (left panel), and for financial and government-related firms vs. tradable firms (right panel). While the average CAR across all firms is close to 0 over the entire interval, this is not the case either for financial and government-related firms or for tradable firms. Average CARs of both groups of firms are close to 0 in the days before the announcement, but sharply diverge after the announcement date. In particular, the CAR of financial and government-related firms turns positive after the announcement while that of tradable firms becomes negative.

Table 4 separately reports the average post-announcement 2-day CAR of financial, government-related, and tradable firms. In the two days after the announcement, the CARs of financial firms are on average 0.65 percentage points, and those of government-related firms are on average 0.85 percentage points (both statistically different from zero under all models). Instead, the CARs of tradable firms are negative (but not statistically different from zero). These estimates, however, do not take into account the potential overlap between the different groups of firms. For instance, some tradable firms might also be government-related. Additionally, they do not 


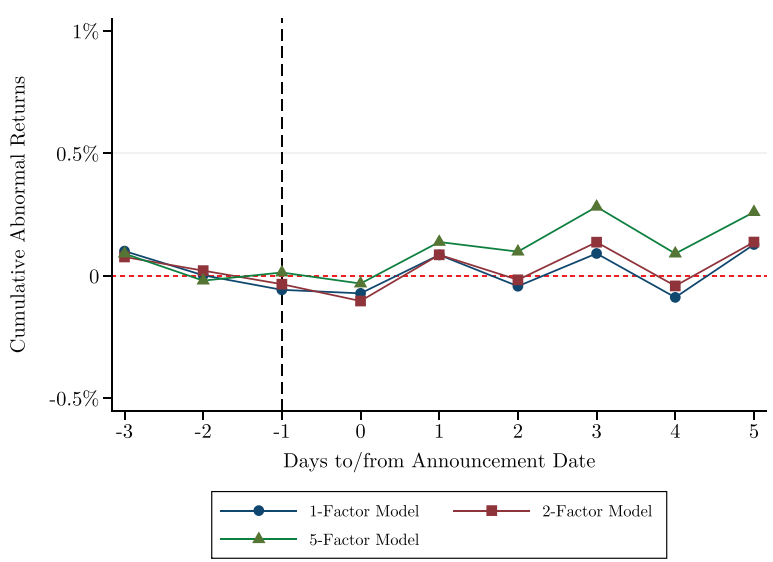

All firms

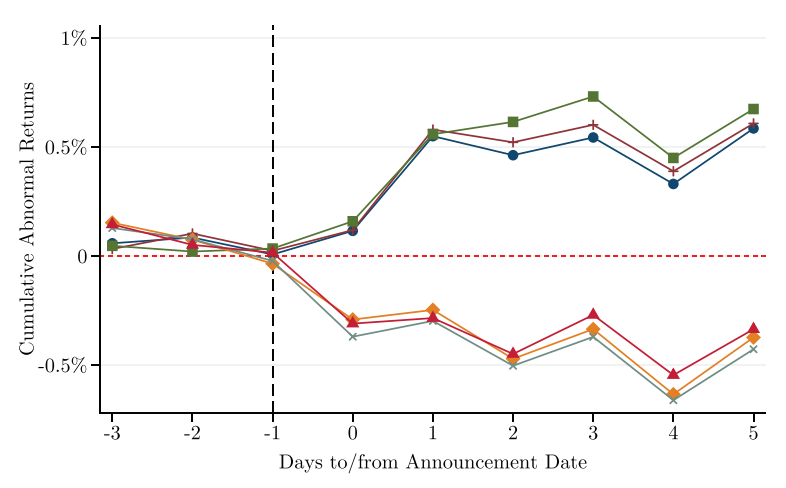

- Gvt\&Fin (1-Factor Model)+ Gvt\&Fin (2-Factor Model)- Gvt\&Fin (5-Factor Model) - Trad (1-Factor Model) $* \operatorname{Trad}\left(2-\right.$ Factor Model) $\_$Trad (5-Factor Model)

Financial \& Government-related vs. tradable firms

Fig. 9. Cumulative abnormal returns around events. This figure depicts the evolution of the cumulative abnormal returns of domestic firms over a time window which starts 3 days before the announcement of each country's inclusion in the corresponding index, and ends 5 days after it. The left panel depicts the cumulative abnormal returns of all firms, while the right panel depicts the cumulative abnormal returns of financial and government-related firms, and tradable firms, separately. Cumulative abnormal returns are computed using three models. The only risk factor in the 1-factor model is the return of the MSCI Emerging Markets Index; the two risk factors in the 2-factor model are the return of the MSCI Emerging Markets Index and the return of the MSCI World Index; the 5-factor models include these two risk factors plus small minus big (SMB), high minus low (HML), and momentum (WML) factors. The vertical dashed line indicates the last trading day before the announcement. Observations in the top and the bottom percentile of the country-by-date distribution of cumulative abnormal returns are excluded.

Table 4

Cumulative abnormal returns, by firm type.

\begin{tabular}{|c|c|c|c|c|}
\hline \multicolumn{5}{|l|}{ Panel A: Financial firms } \\
\hline & Demeaned Returns & 1-Factor Model & 2-Factor Model & 5-Factor Model \\
\hline Average 2-day CAR & $\begin{array}{l}0.688^{* * * *} \\
(0.181)\end{array}$ & $\begin{array}{l}0.666^{* * *} \\
(0.173)\end{array}$ & $\begin{array}{l}0.643^{* * * *} \\
(0.166)\end{array}$ & $\begin{array}{l}0.607^{* * * *} \\
(0.183)\end{array}$ \\
\hline Number of Countries & 6 & 6 & 6 & 6 \\
\hline Observations & 118 & 118 & 118 & 118 \\
\hline \multicolumn{5}{|c|}{ Panel B: Government-related firms } \\
\hline & Demeaned Returns & 1-Factor Model & 2-Factor Model & 5-Factor Model \\
\hline Average 2-day CAR & $\begin{array}{l}0.909^{* * * *} \\
(0.237)\end{array}$ & $\begin{array}{l}0.802^{* * * *} \\
(0.245)\end{array}$ & $\begin{array}{l}0.831^{* * * *} \\
(0.247)\end{array}$ & $\begin{array}{l}0.866^{* * * *} \\
(0.250)\end{array}$ \\
\hline Number of Countries & 6 & 6 & 6 & 6 \\
\hline Observations & 78 & 78 & 78 & 78 \\
\hline \multicolumn{5}{|l|}{ Panel C: Tradable firms } \\
\hline & Demeaned Returns & 1-Factor Model & 2-Factor Model & 5-Factor Model \\
\hline Average 2-day CAR & $\begin{array}{l}-0.132 \\
(0.173)\end{array}$ & $\begin{array}{l}-0.205 \\
(0.166)\end{array}$ & $\begin{array}{l}-0.239 \\
(0.165)\end{array}$ & $\begin{array}{l}-0.202 \\
(0.177)\end{array}$ \\
\hline Number of Countries & 6 & 6 & 6 & 6 \\
\hline Observations & 306 & 305 & 305 & 304 \\
\hline
\end{tabular}

This table reports the average cumulative abnormal return of financial firms (Panel A), government-related firms (Panel B), and firms operating in tradable sectors (Panel C) in the 2 days following the announcement of each country's inclusion in the corresponding index. CARs in the first column (the demeaned returns) are computed as the cumulated differences between the daily returns and the average daily return in the year preceding the announcement. CARs in columns 2 to 4 are computed using three different factor models. The only risk factor in the 1-factor model is the return of the MSCI Emerging Markets Index; the two risk factors in the 2-factor model are the return of the MSCI Emerging Markets Index and the return of the MSCI World Index; the 5-factor model include these two risk factors plus small minus big (SMB), high minus low (HML), and momentum (WML) factors. Observations in the top and the bottom percentile of the country-specific distribution of 2-day cumulative abnormal returns are excluded. Standard errors in parenthesis are clustered at the country-by-industry level. *, **, ***, denote that the the average CAR is statistically different from 0 at the $10 \%, 5 \%$, and $1 \%$ confidence level, respectively. 
take into account heterogeneity in financial dependence, which may crucially affect how firms benefit from capital inflows. To take this into account, we estimate the following equation:

$$
C A R_{i}=\alpha+\beta_{1} \mathbb{1}(\text { Financial })_{i}+\beta_{2} \mathbb{1}(\text { Govt })_{i}+\beta_{3} \mathbb{1}(\text { Tradable })_{i}+\beta_{4} \text { EFD }_{i}+\varepsilon_{i}
$$

where $\mathbb{1}$ (Financial), $\mathbb{1}($ Govt), and $\mathbb{1}$ (Tradable) are as defined in Section 2.2, and $\varepsilon$ is an error term.

Results are reported in Table 5. Financial and government-related firms experience larger than average CARs in the two days following the announcement episode. The estimated coefficients are statistically significant in all models and range from 0.53 to 0.61 for the financial indicator $\mathbb{1}$ (Financial) and from 0.6 to 0.7 for the government-relatedness indicator $\mathbb{1}$ (Govt). ${ }^{28}$ Instead, tradable firms experience significantly lower than average CARs in the 2 days following the announcement. The estimated coefficients of $\mathbb{1}$ (Tradable) ranges from -0.45 to -0.51 , and is statistically significant in all models. Moreover, Table 5 reports the difference between the coefficients on financial and tradable firms and between government-related and tradable firms. In all models, these differences are statistically significant at the 99\% confidence level. Finally, the coefficient of EFD is positive and significant under all specifications, which is consistent with the hypothesis that financially-dependent firms benefit more from capital inflows. Quantitatively, a one-standard deviation increase in financial dependence increases the 2-day CAR by approximately 0.22 percentage points. $^{29}$

In Table 6, we add additional firm-specific controls: $\mathrm{i}$ ) an indicator variable $\mathbb{1}$ (IssueDebt), which equals 1 for firms that have access to the corporate debt market (either through corporate bonds or syndicated loans) ${ }^{30}$; ii) an indicator variable $\mathbb{1}($ ForOwnership), which equals 1 if a stock is also included in the MSCI Emerging Markets Index, and is therefore more likely held by foreigners; iii) size, measured by the logarithm of total assets. None of the additional controls are statistically significant and their inclusion does not significantly affect our coefficients of interest. ${ }^{31}$

\subsection{Cross-country variation}

We have shown that, after announcement episodes, financial and government-related firms have higher than average CARs while tradable firms have lower than average CARs. These findings do not exploit the cross-country variation in the behavior of sovereign bond yields and exchange rates described in Section 3. Such heterogeneity is potentially important because, according to the discussion in Section 2, the effect of the announcement should be larger i) on financial and government-related firms in countries with larger reductions in sovereign bond yields, and ii) on tradable firms in countries with larger exchange-rate appreciations. We now present additional evidence that supports these two hypotheses.

We first estimate six separate regressions, one for each country, of the form

$$
C A R_{i}=\alpha+\beta_{1} \mathbb{1}\left(\text { Govt } \mathcal{E}^{\prime} \text { Fin }\right)_{i}+\beta_{2} \mathbb{1}(\text { Tradable })_{i}+\beta_{3} E F D_{i}+\varepsilon_{i}
$$

where $\mathbb{1}$ (Govt \& Fin) is an indicator variable that takes value 1 for financial and government-related firms. Then, in Fig. 10, we plot the estimated $\beta_{1}$ coefficient as a function of the country-specific 2-day change in the 5-year local currency sovereign bond yield (left panel) and the estimated $\beta_{2}$ as a function of the country-specific 2-day currency appreciation. The figure shows that, as expected, the magnitudes of these coefficients are related with the post-announcement changes in sovereign bond yields and exchange rates. In particular, the CARs of financial and government-related firms are larger in countries that experience a larger reduction in the sovereign yield in the two days following the announcement. Moreover, the CARs of tradable firms are smaller in countries that experience a larger appreciation of the domestic currency in the two days following the announcement. $^{32}$

\footnotetext{
28 In Table A1 in the Appendix, we also estimate our main specification separating between firms partially owned by the government and firms with close relationship with it. We find both coefficients to be positive (even though the latter is not significant, most likely because of the small number of firms partially owned by the government in our sample) and of a similar magnitude. This suggests that the positive effect on government-related firms is driven by both government ownership and reliance on government demand.

${ }^{29}$ In Table A2 in the Appendix, we show that our main results are robust to: i) excluding illiquid stocks, that is stocks whose price never change in the 20 trading days around the announcement date; ii) reducing the weight of firms with more than one stock, by considering for each of these companies only the average 2-day CAR of the company's traded securities; iii) excluding Czech Republic and Nigeria from our sample, which are somewhat particular as we mentioned in Section 2.2. In all cases, our results are quantitatively and qualitatively very close to those in Table 5. Further, in Table A3 we show that our results are robust to controlling for country fixed effects. Finally, in Table A4, Panel A, we replicate our estimates in the days prior to the announcement, using as dependent variable the CARs in the interval [ $t-3, t-2]$, where $t$ is the first trading day after the announcement. None of the 16 coefficients of interest is statistically significant at the $95 \%$ confidence level, and only one is statistically different from 0 at the $90 \%$ confidence level.

${ }^{30}$ In principle, firms issuing bonds could benefit from reductions in government bond yields, as highlighted in Dittmar (2008). At the same time, these firms are more likely to be the least financially constrained (within each industry), so that the overall effect is a priori ambiguous.

31 When controlling for size, some coefficients fall below the conventional significance threshold, although the differences between the coefficients of financial and tradable firms and of government-related and tradable firms remain statistically significant. The lower significance is likely due to the fact that controlling for size reduces the sample since balance sheet data are missing for almost 200 firms.

${ }^{32}$ In Section 5, we discuss some potential determinants of the differential effects of the inclusion announcements on sovereign bond yields and exchange rates across countries.
} 
Table 5

Main results.

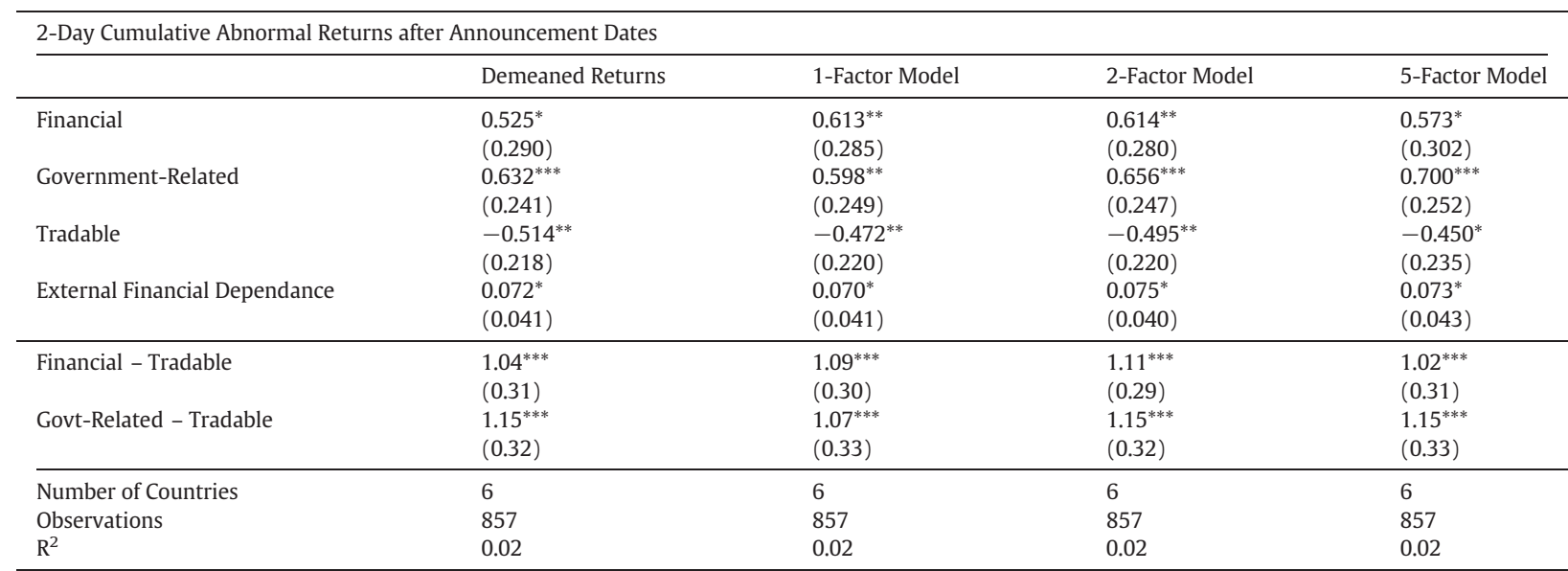

This table reports the OLS coefficients of a regression where the dependent variable is the CAR of each firm in the 2 days following the announcement of each country's inclusion in the corresponding index. The explanatory variables are: Financial, which is an indicator variable that is equal to 1 for financial firms; Government-Related, which is an indicator variable that is equal to 1 for government-related firms; Tradable, which is an indicator variable equal to for firms in tradable industries (according to the classification in Mian and Sufi (2014)); and External Financial Dependance, which is a measure of firms' dependance on external financing sources, computed following Rajan and Zingales (1998). The table reports also the difference between the estimated coefficient on Financial and that on Tradable, as well as the difference between the estimated coefficients on Government-Related and that on Tradable. CARs in the first column (the demeaned returns) are computed as the the cumulated differences between the daily returns and the average daily return in the year preceding the announcement. CARs in columns 2 to 4 are computed using three different factor models. The only risk factor in the 1-factor model is the return of the MSCI Emerging Markets Index; the two risk factors in the 2-factor model are the return of the MSCI Emerging Markets Index and the return of the MSCI World Index; the 5-factor model include these two risk factors plus small minus big (SMB), high minus low (HML), and momentum (WML) factors. Observations in the top and the bottom percentile of the country-specific distribution of 2-day cumulative abnormal returns are excluded. Standard errors in parenthesis are clustered at the country-by-industry level. * $* *, * * *$, denote significance at the $10 \%, 5 \%$, and $1 \%$ confidence level, respectively.

To quantitatively assess the relationship between changes in government bond yields and exchange rates and CARs around the announcements we estimate the following equation:

$$
C A R_{i c}=\theta_{c}+\beta_{1} \mathbb{1}(\text { Govt\&Fin })_{i} \times \Delta \text { Yield }_{c}+\beta_{2} \mathbb{1}\left(\text { Tradable }_{i} \times \% \Delta \text { ExchRate }_{c}+\beta_{3} \text { EFD }_{i}+\varepsilon_{i c}\right.
$$

where: $\theta_{c}$ are country fixed effects, and $\mathbb{1}$ (Govt \& Fin) and $\mathbb{1}$ (Tradable) are respectively interacted with the country-specific 2-day change in the 5-year local currency sovereign bond yield ( $\Delta$ Yield) and the 2-day currency appreciation (\% $\Delta$ ExchRate). Larger values of $\Delta$ Yield correspond to larger reductions in sovereign bond yields and larger values of \% $\Delta$ ExchRate correspond to larger appreciations. Under this specification, the $\beta_{1}$ coefficient captures the cross-country relationship between the reduction in the sovereign bond yield and the CARs of financial and government-related firms. Similarly, the $\beta_{2}$ coefficient captures the relationship between the appreciation of the domestic currency and the CARs of tradable firms. ${ }^{33}$

Table 7 shows that both interaction terms are statistically significant and of the expected sign. Quantitatively, these estimates imply that a sovereign debt inflow shock that reduces the 5-year government bond yield by 100 basis points increases the CARs of financial and government-related firms by 1.7 percentage points. Conversely, a sovereign debt inflow shock that leads to a $1 \%$ appreciation of the domestic currency reduces the CARs of tradable firms by 0.41 percentage points. $^{34}$

\section{Further questions}

We have established that sovereign debt inflows have heterogeneous effects on domestic stock prices. We now explore a few additional questions around this main result. First, we analyze the extent to which the implied size of the inflow shocks matters for the magnitude of the response of sovereign yields and exchange rates. Second, we explore whether the effects of expected inflows are fully incorporated into prices at the time of announcement. Third, although our results can be rationalized by expected changes in cash flows, we explore here whether they might also reflect changes in discount rates.

\footnotetext{
33 This regression does not include the dummies $\mathbb{1}(\text { Govt \& Fin })_{i}$ and $\mathbb{1}$ (Tradable $)_{i}$, thus assuming that they have no effect other than through their interaction with the government bond yield and the exchange rate. In fact, when included in the regressions, neither is statistically significant. The coefficients of the interaction terms remain of comparable magnitude, even though in some cases the coefficient on $\mathbb{1}$ (Govt \& Fin $)_{i} \times \Delta$ Yield $_{c}$ falls below the conventional significance level.

${ }^{34}$ Panel B of Table A4 reports the results of a placebo test and shows that none of our results change Panel B, we present the results of a placebo test and shows that none of these results hold if we use the CARs over the interval [ $t-3, t-2]$, where $t$ is the first trading day after the announcement.
} 
Table 6

Additional controls.

\begin{tabular}{|c|c|c|c|c|c|c|c|c|}
\hline \multicolumn{9}{|c|}{ 2-Day Cumulative Abnormal Returns after Announcement Dates } \\
\hline \multirow[b]{2}{*}{ Financial } & \multicolumn{2}{|c|}{ Demeaned Returns } & \multicolumn{2}{|c|}{ 1-Factor Model } & \multicolumn{2}{|c|}{ 2-Factor Model } & \multicolumn{2}{|c|}{ 5-Factor Model } \\
\hline & $\begin{array}{l}0.497^{*} \\
(0.276)\end{array}$ & $\begin{array}{l}0.494 \\
(0.339)\end{array}$ & $\begin{array}{l}0.584^{* *} \\
(0.275)\end{array}$ & $\begin{array}{l}0.618^{*} \\
(0.336)\end{array}$ & $\begin{array}{l}0.569 * * \\
(0.271)\end{array}$ & $\begin{array}{l}0.557^{*} \\
(0.329)\end{array}$ & $\begin{array}{l}0.578^{*} \\
(0.297)\end{array}$ & $\begin{array}{l}0.539 \\
(0.364)\end{array}$ \\
\hline Government-Related & $\begin{array}{l}0.505^{* *} \\
(0.237)\end{array}$ & $\begin{array}{l}0.451^{*} \\
(0.264)\end{array}$ & $\begin{array}{l}0.500^{* *} \\
(0.244)\end{array}$ & $\begin{array}{l}0.441 \\
(0.270)\end{array}$ & $\begin{array}{l}0.569 * * \\
(0.243)\end{array}$ & $\begin{array}{l}0.498^{*} \\
(0.271)\end{array}$ & $\begin{array}{l}0.641^{* * * *} \\
(0.245)\end{array}$ & $\begin{array}{l}0.557^{* *} \\
(0.271)\end{array}$ \\
\hline Tradable & $\begin{array}{l}-0.431^{*} \\
(0.226)\end{array}$ & $\begin{array}{l}-0.539^{* *} \\
(0.273)\end{array}$ & $\begin{array}{l}-0.398^{*} \\
(0.226)\end{array}$ & $\begin{array}{l}-0.499^{*} \\
(0.279)\end{array}$ & $\begin{array}{l}-0.421^{*} \\
(0.227)\end{array}$ & $\begin{array}{l}-0.533^{*} \\
(0.279)\end{array}$ & $\begin{array}{l}-0.364 \\
(0.246)\end{array}$ & $\begin{array}{l}-0.431 \\
(0.307)\end{array}$ \\
\hline External Financial Dependance & $\begin{array}{l}0.074^{*} \\
(0.041)\end{array}$ & $\begin{array}{l}0.083^{*} \\
(0.048)\end{array}$ & $\begin{array}{l}0.072^{*} \\
(0.042)\end{array}$ & $\begin{array}{l}0.083^{*} \\
(0.050)\end{array}$ & $\begin{array}{l}0.076^{*} \\
(0.041)\end{array}$ & $\begin{array}{l}0.087^{*} \\
(0.049)\end{array}$ & $\begin{array}{l}0.076^{*} \\
(0.043)\end{array}$ & $\begin{array}{l}0.085^{*} \\
(0.051)\end{array}$ \\
\hline Foreign Ownership & $\begin{array}{l}0.222 \\
(0.243)\end{array}$ & $\begin{array}{l}0.112 \\
(0.262)\end{array}$ & $\begin{array}{l}0.073 \\
(0.255)\end{array}$ & $\begin{array}{l}0.002 \\
(0.278)\end{array}$ & $\begin{array}{l}0.049 \\
(0.249)\end{array}$ & $\begin{array}{l}-0.092 \\
(0.277)\end{array}$ & $\begin{array}{l}0.056 \\
(0.249)\end{array}$ & $\begin{array}{l}-0.089 \\
(0.283)\end{array}$ \\
\hline Issue Debt & $\begin{array}{l}0.133 \\
(0.246)\end{array}$ & $\begin{array}{l}0.087 \\
(0.266)\end{array}$ & $\begin{array}{l}0.040 \\
(0.253)\end{array}$ & $\begin{array}{l}0.010 \\
(0.274)\end{array}$ & $\begin{array}{l}0.008 \\
(0.268)\end{array}$ & $\begin{array}{l}-0.049 \\
(0.295)\end{array}$ & $\begin{array}{l}-0.042 \\
(0.279)\end{array}$ & $\begin{array}{l}-0.113 \\
(0.314)\end{array}$ \\
\hline Log(Assets) & & $\begin{array}{l}0.026 \\
(0.046)\end{array}$ & & $\begin{array}{l}0.013 \\
(0.046)\end{array}$ & & $\begin{array}{l}0.039 \\
(0.049)\end{array}$ & & $\begin{array}{l}0.046 \\
(0.060)\end{array}$ \\
\hline Country FE & Yes & Yes & Yes & Yes & Yes & Yes & Yes & Yes \\
\hline Financial - Tradable & $\begin{array}{l}0.93^{* * *} \\
(0.29)\end{array}$ & $\begin{array}{l}1.03^{* * *} \\
(0.37)\end{array}$ & $\begin{array}{l}0.98^{* * *} \\
(0.29)\end{array}$ & $\begin{array}{l}1.12^{* * *} \\
(0.36)\end{array}$ & $\begin{array}{l}0.99^{* * * *} \\
(0.28)\end{array}$ & $\begin{array}{l}1.09^{* * *} \\
(0.35)\end{array}$ & $\begin{array}{l}0.94^{* * * *} \\
(0.31)\end{array}$ & $\begin{array}{l}0.97^{* *} \\
(0.39)\end{array}$ \\
\hline Govt-Related - Tradable & $\begin{array}{l}0.94^{* * *} \\
(0.32)\end{array}$ & $\begin{array}{l}0.99^{* * *} \\
(0.37)\end{array}$ & $\begin{array}{l}0.90^{* * *} \\
(0.33)\end{array}$ & $\begin{array}{l}0.94^{* *} \\
(0.39)\end{array}$ & $\begin{array}{l}0.99^{* * * *} \\
(0.33)\end{array}$ & $\begin{array}{l}1.03^{* * * *} \\
(0.39)\end{array}$ & $\begin{array}{l}1.01^{* * * *} \\
(0.34)\end{array}$ & $\begin{array}{l}0.99^{* *} \\
(0.40)\end{array}$ \\
\hline Number of Countries & 6 & 6 & 6 & 6 & 6 & 6 & 6 & 6 \\
\hline Observations & 857 & 663 & 857 & 663 & 857 & 663 & 857 & 664 \\
\hline $\mathrm{R}^{2}$ & 0.04 & 0.04 & 0.04 & 0.04 & 0.04 & 0.04 & 0.03 & 0.03 \\
\hline
\end{tabular}

This table reports the OLS coefficients of a regression where the dependent variable is the CAR of each firm in the 2 days following the announcement of each country's inclusion in the corresponding index. The explanatory variables are: Financial, which is an indicator variable that is equal to 1 for financial firms; Government-Related, which is an indicator variable that is equal to 1 for government-related firms; Tradable, which is an indicator variable equal to for firms in tradable industries (according to the classification in Mian and Sufi (2014)); External Financial Dependance, which is a measure of firms' dependance on external financing sources, computed following Rajan and Zingales (1998); Foreign Ownership, which is an indicator variable that is equal to 1 for firms which are included in the MSCI Emerging Markets Index in the year prior to the announcement date; IssueDebt, which is an indicator variable that is equal to 1 for firms that issued corporate debt or obtained a syndicated loan in the years before the announcement date; and Log(Assets), which is the logarithm of the total value of a firm's assets. All regressions include country fixed effects. The table reports also the difference between the estimated coefficient on Financial and that on Tradable, as well as the difference between the estimated coefficients on Government-Related and that on Tradable. CARs in the first column (the demeaned returns) are computed as the cumulated differences between the daily returns and the average daily return in the year preceding the announcement. CARs in columns 2 to 4 are computed using three different factor models. The only risk factor in the 1-factor model is the return of the MSCI Emerging Markets Index; the two risk factors in the 2-factor model are the return of the MSCI Emerging Markets Index and the return of the MSCI World Index; the 5-factor model include these two risk factors plus small minus big (SMB), high minus low (HML), and momentum (WML) factors. Observations in the top and the bottom percentile of the country-specific distribution of 2-day cumulative abnormal returns are excluded. Standard errors in parenthesis are clustered at the country-by-industry level. ${ }^{*},{ }^{* *},{ }^{* * *}$, denote significance at the $10 \%, 5 \%$, and $1 \%$ confidence level, respectively.
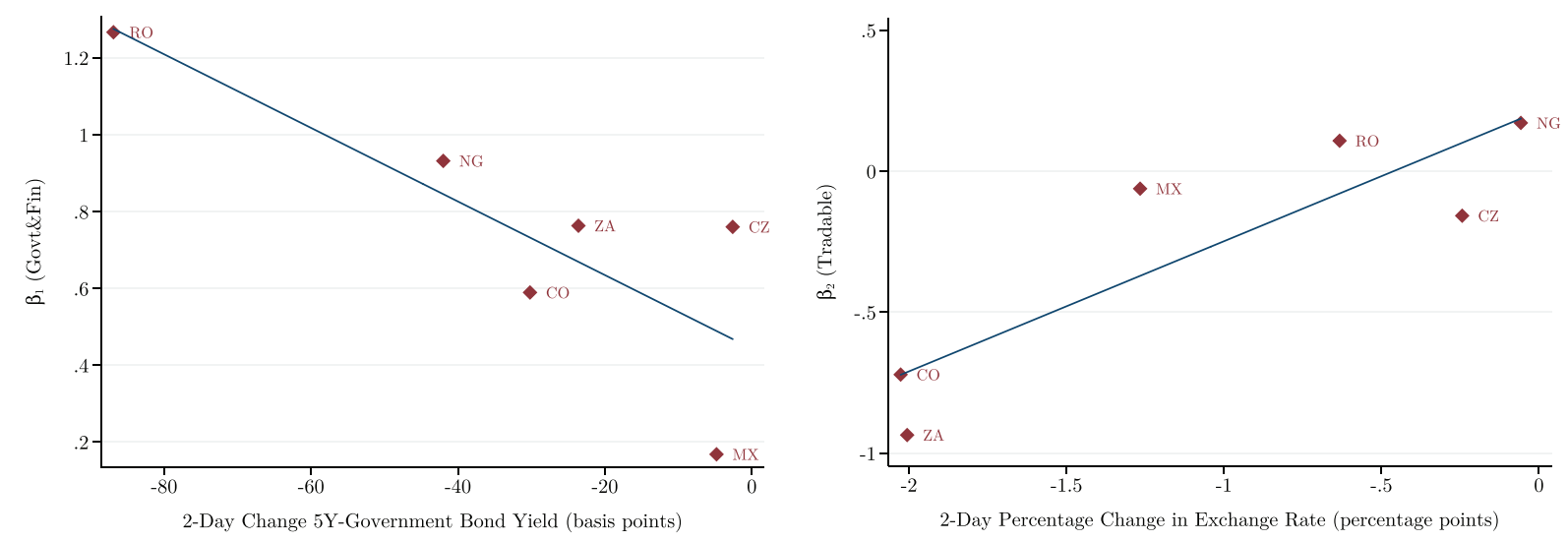

Fig. 10. Heterogeneous effects of the shocks. This figure depicts the relationship between the size of the 2-day changes in sovereign bond yields and exchange rates (in the two days following the announcement of each country's inclusion in the corresponding index), and the stock market effects on government-related and financial firms (left panel), and tradable firms (right panel), separately. $\beta_{1}$ and $\beta_{2}$ are the OLS estimated coefficients of 6 country-specific regressions of the form: CAR $=\beta_{1} \mathbb{1}$ (Govt \& Fin) $+\beta_{2} \mathbb{1}$ (Tradable) $+\beta_{3} E F D+\varepsilon$, where CAR is the cumulative abnormal returns of each firm in the two days following the announcement episode (computed using a 1-factor model where the only risk factor is the return of the MSCI Emerging Markets Index), $\mathbb{1}$ (Govt \& Fin) is a dummy variable which equals 1 for government-related and financial companies, $\mathbb{1}$ (Tradable) is a dummy which equals 1 for firms operating in tradable sectors, and EFD is a measure of external financial dependance computed at the industry-level. Observations in the top and the bottom percentile of the country-specific distribution of 2-day cumulative abnormal returns are excluded. 
Table 7

Interaction with size of the shocks.

\begin{tabular}{|c|c|c|c|c|c|c|c|c|}
\hline \multicolumn{9}{|c|}{ 2-Day Cumulative Abnormal Returns after Announcement Dates } \\
\hline \multirow[b]{2}{*}{$\Delta$ Yield $\times$ Govt $\&$ Fin } & \multicolumn{2}{|c|}{ Demeaned Returns } & \multicolumn{2}{|c|}{ 1-Factor Model } & \multicolumn{2}{|c|}{ 2-Factor Model } & \multicolumn{2}{|c|}{ 5-Factor Model } \\
\hline & $\begin{array}{l}0.015^{* * *} \\
(0.005)\end{array}$ & $\begin{array}{l}0.017^{* * *} \\
(0.006)\end{array}$ & $\begin{array}{l}0.015^{* * *} \\
(0.005)\end{array}$ & $\begin{array}{l}0.017^{* * * *} \\
(0.006)\end{array}$ & $\begin{array}{l}0.015^{* * *} \\
(0.005)\end{array}$ & $\begin{array}{l}0.017^{* * * *} \\
(0.006)\end{array}$ & $\begin{array}{l}0.015^{* * * *} \\
(0.005)\end{array}$ & $\begin{array}{l}0.017^{* * * *} \\
(0.006)\end{array}$ \\
\hline$\% \Delta$ ExchRate $\times$ Tradable & $\begin{array}{l}-0.354^{* * *} \\
(0.147)\end{array}$ & $\begin{array}{l}-0.411^{* * *} \\
(0.144)\end{array}$ & $\begin{array}{l}-0.341^{* *} \\
(0.145)\end{array}$ & $\begin{array}{l}-0.393^{* * *} \\
(0.144)\end{array}$ & $\begin{array}{l}-0.358^{* *} \\
(0.146)\end{array}$ & $\begin{array}{l}-0.414^{* * *} \\
(0.144)\end{array}$ & $\begin{array}{l}-0.295^{*} \\
(0.166)\end{array}$ & $\begin{array}{l}-0.349^{* *} \\
(0.162)\end{array}$ \\
\hline External Financial Dependance & & $\begin{array}{l}0.070^{*} \\
(0.038)\end{array}$ & & $\begin{array}{l}0.066 \\
(0.040)\end{array}$ & & $\begin{array}{l}0.070^{*} \\
(0.039)\end{array}$ & & $\begin{array}{l}0.068^{*} \\
(0.041)\end{array}$ \\
\hline Country FE & Yes & Yes & Yes & Yes & Yes & Yes & Yes & Yes \\
\hline Number of Countries & 6 & 6 & 6 & 6 & 6 & 6 & 6 & 6 \\
\hline Observations & 861 & 857 & 861 & 857 & 861 & 857 & 861 & 857 \\
\hline $\mathrm{R}^{2}$ & 0.04 & 0.04 & 0.04 & 0.04 & 0.04 & 0.04 & 0.03 & 0.04 \\
\hline
\end{tabular}

This table reports the OLS coefficients of a regression where the dependent variable is the CAR of each firm in the 2 days following the announcement of each country's inclusion in the corresponding index. The explanatory variables are: $\Delta$ Yield $\times$ Govt \& Fin, which is the product of indicator variable that is equal to 1 for financial and government-related firms, and the 2-day change in the 5-year local currency government bond yield, in basis points; \% $\Delta$ ExchRate $\times$ Tradable, which is the product of indicator variable that is equal to 1 for firms in tradable industries (according to the classification in Mian and Sufi (2014)), and the 2day percentage change in the exchange rate (computed as the difference in the log of the exchange rate) in percentage points; and External Financial Dependance, which is a measure of firms' dependance on external financing sources, computed following Rajan and Zingales (1998). All regressions include country fixed effects. CARs in the first column (the demeaned returns) are computed as the cumulated differences between the daily returns and the average daily return in the year preceding the announcement. CARs in columns 2 to 4 are computed using three different factor models. The only risk factor in the 1 -factor model is the return of the MSCI Emerging Markets Index; the two risk factors in the 2-factor model are the return of the MSCI Emerging Markets Index and the return of the MSCl World Index; the 5-factor models include these two risk factors plus small minus big (SMB), high minus low (HML), and momentum (WML) factors. Observations in the top and the bottom percentile of the country-specific distribution of 2-day cumulative abnormal returns are excluded. Standard errors in parenthesis are clustered at the country-by-industry level. ${ }^{*},{ }^{* *},{ }^{* * *}$, denote significance at the $10 \%, 5 \%$, and $1 \%$ confidence level, respectively.

\subsection{Does the size of inflows matter?}

The evidence in Section 4.3 shows that the effects of the index-inclusion announcements on stock prices are related to the size of the changes in sovereign bond yields and exchange rates following the announcements. In this section, we test whether these changes are related to the magnitude of the expected capital inflows as a result of inclusion in the index. First, for each announcement, we compute the estimated inflows as the announced change in benchmark weight of each country - calculated over the entire implementation period - multiplied by the assets under management of funds benchmarked against the corresponding index. We normalize these inflows either by the total value of local-currency sovereign bonds that are to be included in the index, or by GDP. In principle, we would expect the effect on yields to be increasing in the first measure, which captures the size of the inflows relative to the market of the included bonds. Likewise, we would expect the effect on the exchange rate to be increasing in the second measure, which captures the size of inflows relative to the economy.

Fig. 11 shows that both conjectures are verified in the data. Panel A shows that there is a positive relation between the postannouncement change in local-currency sovereign yields and the estimated inflows relative to the size of the affected bond markets. Panel B shows that there is a positive relation between the post-announcement appreciation of the domestic currency and the estimated inflows relative to GDP. The only country that appears to be in outlier in both figures is Czech Republic, where the size of inflows is likely to be overestimated because - as we have already explained - the inclusion episode is accompanied by a simultaneous exclusion from another index.

\subsection{Is it all in the announcement?}

Throughout, we analyze the effects of sovereign debt inflows on prices at the time of an inclusion announcement. But it could be argued that some of these effects will take place at the time of implementation, between 2 and 6 months after the announcement, when passive investors actually rebalance their portfolios. ${ }^{35}$ Even if expected, these inflows at the time of implementation could still affect prices in the presence of limited arbitrage (Hau, 2011). To see whether this is the case, we analyze the behavior of sovereign bond prices on the implementation dates.

Fig. 12 depicts the change in the log price of 5-year local currency sovereign bonds in the 15 trading days around each implementation date. As the figure shows, the price of sovereign bonds does not move significantly on these dates, differently from its behavior in the aftermath of announcements when it increases by almost $2 \%$ in 5 days (Fig. 8). We also analyze stock market effects at the time of implementation by running our main regression by using price changes in the two days following implementation. Table 8 reports that none of the coefficients is significantly different from zero. Overall, this suggests that most of the effects on bond and stock prices take place at the time of announcement.

\footnotetext{
$\overline{35}$ See Raddatz et al. (2017) for evidence of portfolio rebalancing at the time of implementation.
} 


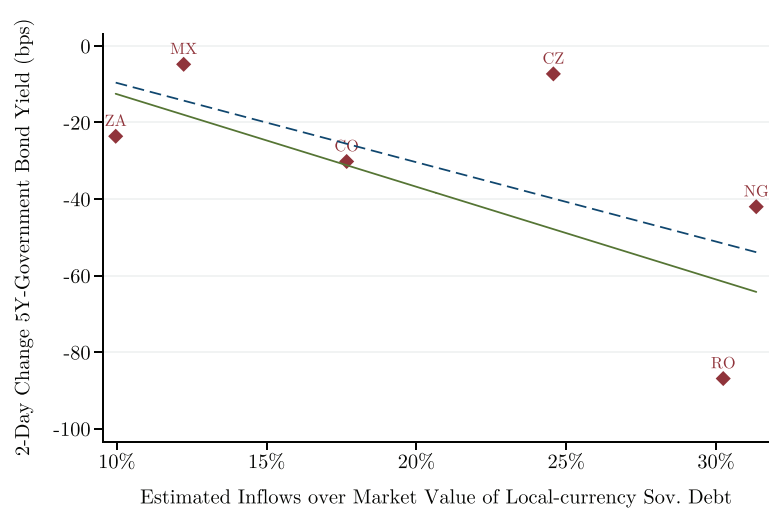

Estimated Inflows over Market Value of Locat

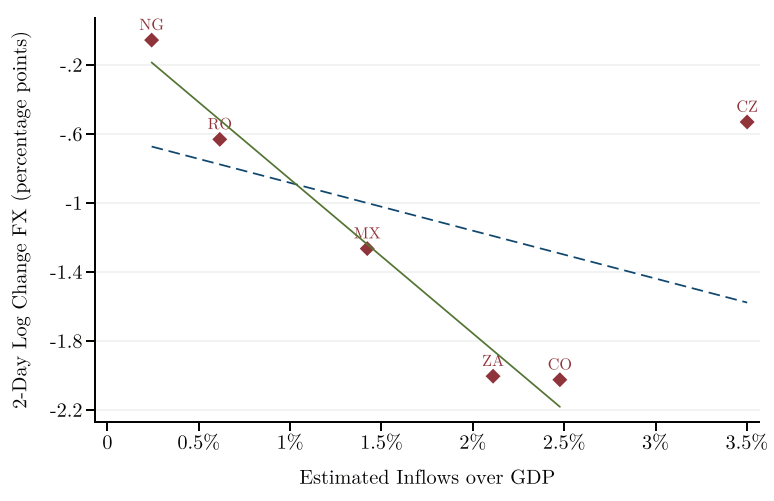

---- All countries $\longrightarrow$ Excluding Czech Republic

Fig. 11. Estimated inflows and size of the shocks. This figure depicts the relationship between the size of the 2-day changes in sovereign bond yields and exchange rates (in the two days following the announcement of each country's inclusion in the corresponding index), and the estimated sovereign debt inflows relative to the size of each country's local-currency sovereign debt market (left panel) and each country's GDP (right panel), separately. The estimated inflows, the market value of sovereign debt markets, and countries' GDP are in US dollars. Estimated inflows are computed as the change in benchmark weight following the inclusion of each country in the index, calculated over the entire implementation period, multiplied by the assets under management of funds tracking their returns against the corresponding index. The dashed and the solid line are regression lines describing the relationship between estimated inflows and shocks, with and without Czech Republic, respectively.

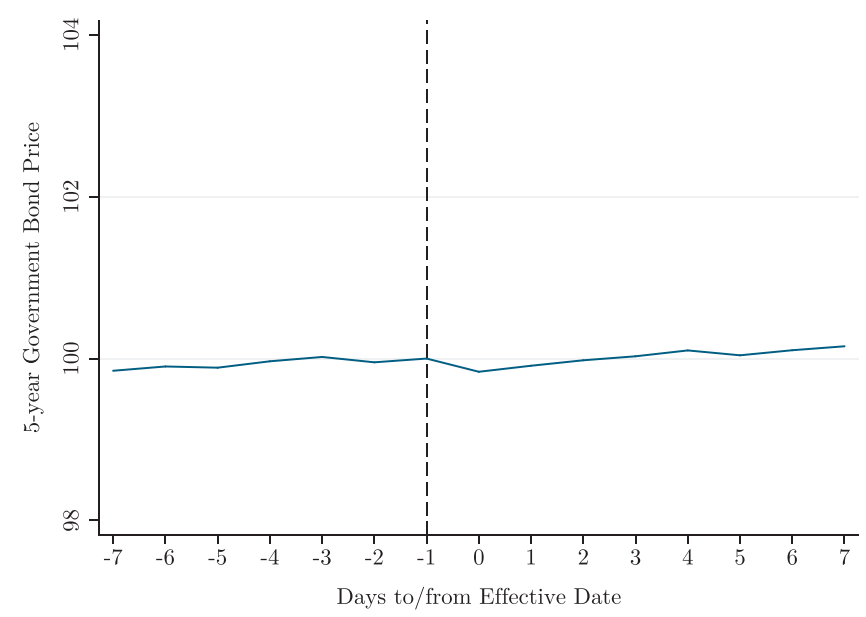

Fig. 12. 5-Year Government bond prices around implementation. This figure depicts the time series of the average 5-year local currency government bond prices across Colombia, Czech Republic, Mexico, Nigeria, Romania and South Africa over a time window which starts 7 trading days before the implementation date, and ends 7 trading days after it. The index (which is equal to 100 in the day before the announcement for each country) is constructed by taking the average change in log prices first across implementations for each country, and then across countries. The vertical dashed line indicates the last trading day before each implementation episode.

\subsection{What drives the stock market effects?}

Stock prices are the present discounted value of dividends. Thus, their variation at the time of inclusion announcements could be driven by changes in either future dividends or the "discount rate", i.e. the rate at which investors discount these dividends. The asset pricing literature has indeed shown that episodes of equity market liberalization or inclusion in international indexes impact stock prices partly through their effects on discount rates. For instance, Henry (2000) shows that in the aftermath of equity market liberalizations, the equity premium reflects to a greater extent the covariance between domestic cash flows and global returns. As for international equity index rebalancings, Greenwood (2005) and Hau (2011) show that they impact not only those stocks directly affected by the rebalancing but also other correlated risky assets.

We analyze sovereign debt inflows as opposed to equity inflows, so their implications for stock prices through the discount rate are unclear a priori. We nonetheless explore the role played by discount rate effects in our setting in two ways. First, we use the betas with respect to the emerging market portfolio and the global portfolio (obtained estimating the 1-factor and the 
Table 8

Main results on implementation dates.

\begin{tabular}{|c|c|c|c|c|}
\hline \multicolumn{5}{|c|}{ 2-Day Cumulative Abnormal Returns after Announcement Dates } \\
\hline & Demeaned Returns & 1-Factor Model & 2-Factor Model & 5-Factor Model \\
\hline Financial & $\begin{array}{l}0.014 \\
(0.184)\end{array}$ & $\begin{array}{c}-0.065 \\
(0.245)\end{array}$ & $\begin{array}{c}-0.139 \\
(0.241)\end{array}$ & $\begin{array}{c}-0.188 \\
(0.264)\end{array}$ \\
\hline Government-Related & $\begin{array}{l}-0.039 \\
(0.172)\end{array}$ & $\begin{array}{l}-0.062 \\
(0.181)\end{array}$ & $\begin{array}{l}-0.031 \\
(0.179)\end{array}$ & $\begin{array}{l}-0.012 \\
(0.178)\end{array}$ \\
\hline Tradable & $\begin{array}{l}0.009 \\
(0.159)\end{array}$ & $\begin{array}{l}0.028 \\
(0.153)\end{array}$ & $\begin{array}{l}0.052 \\
(0.156)\end{array}$ & $\begin{array}{l}0.043 \\
(0.157)\end{array}$ \\
\hline External Financial Dependance & $\begin{array}{l}-0.034 \\
(0.027)\end{array}$ & $\begin{array}{l}-0.041 \\
(0.028)\end{array}$ & $\begin{array}{l}-0.039 \\
(0.028)\end{array}$ & $\begin{array}{l}-0.061 \\
(0.038)\end{array}$ \\
\hline Number of Countries & 6 & 6 & 6 & 6 \\
\hline Observations & 1781 & 1781 & 1781 & 1781 \\
\hline $\mathrm{R}^{2}$ & 0.00 & 0.00 & 0.00 & 0.00 \\
\hline
\end{tabular}

This table reports the OLS coefficients of a regression where the dependent variable is the CAR of each firm in the 2 days following the implementation of each country's inclusion in the corresponding index. The explanatory variables are: Financial, which is an indicator variable that is equal to 1 for financial firms; Government-Related, which is an indicator variable that is equal to 1 for government-related firms; Tradable, which is an indicator variable equal to for firms in tradable industries (according to the classification in Mian and Sufi (2014)); and External Financial Dependance, which is a measure of firms' dependance on external financing sources, computed following Rajan and Zingales (1998). The table reports also the difference between the estimated coefficient on Financial and that on Tradable, as well as the difference between the estimated coefficients on Government-Related and that on Tradable. CARs in the first column (the demeaned returns) are computed as the the cumulated differences between the daily returns and the average daily return in the year preceding the announcement. CARs in columns 2 to 4 are computed using three different factor models. The only risk factor in the 1-factor model is the return of the MSCI Emerging Markets Index; the two risk factors in the 2-factor model are the return of the MSCI Emerging Markets Index and the return of the MSCI World Index; the 5-factor model include these two risk factors plus small minus big (SMB), high minus low (HML), and momentum (WML) factors. Observations in the top and the bottom percentile of the country-specific distribution of 2-day cumulative abnormal returns are excluded. Standard errors in parenthesis are clustered at the country-by-industry level. *, ${ }^{* *},{ }^{* * *}$, denote significance at the $10 \%, 5 \%$, and $1 \%$ confidence level, respectively.

2-factor models described in Section 4) as additional controls in our main regressions. Table A5 in the Appendix shows that our main coefficients of interests remain unchanged when including firm betas as controls. Also, none of the coefficients of these betas is statistically significant at the $5 \%$ confidence level. Hence, our main results are unlikely to be driven by discount rate effects due to changes in equity premia. Second, we assess whether our results can be explained by changes in stocks' sensitivities to local and global factors due to the rebalancing of investor portfolios. To test for this possibility, we calculate firm betas in the year following the announcement episode and test whether firms' post-announcement betas are different from their pre-announcement betas. Table A6 in the Appendix shows that this is not the case.

This evidence therefore suggests that cash flow effects are the main drivers of our findings. If this is the case, firm outcomes in the medium and long run should reflect the heterogenous response of stock prices to the inclusion announcements. An empirical analysis of these outcomes would require extending the sample substantially beyond the announcements, leading to identification concerns. Pandolfi and Williams (2020) still provide some evidence in this regard. They analyze firm outcomes in the three years following inclusion announcements and find that, consistent with heterogenous cash-flow effects, financial and governmentrelated firms exhibit a larger growth in income, employment, dividends, and total assets relative to tradable firms. In addition, financial dependence is associated with higher growth in dividend payments.

\section{A model of sovereign debt inflows}

We have established that sovereign debt inflows have heterogeneous effects on domestic firms. In particular, the effects are more positive for government-related, financial, and financially-dependent firms than for tradable firms. Section 2 provided an informal discussion of how realistic economic forces can account for these effects. In this section, we present a simple model to formalize our arguments and illustrate the mechanisms at play.

\subsection{Setup}

We consider a small economy that lasts for two periods, $t \in\{0,1\}$. The economy is populated by a continuum of residents of measure one, with preferences:

$$
U\left(C_{N}, C_{T}\right)=\left[\nu \cdot C_{N}^{\frac{\eta-1}{\eta}}+(1-\nu) \cdot C_{T}^{\frac{\eta-1}{\eta}}\right]^{\frac{\eta}{\eta-1}},
$$

where $C_{T}$ and $C_{N}$ respectively denote consumption of tradable and non-tradable goods at $t=1$, and $\eta$ is the elasticity of substitution between both goods. We assume throughout that $\eta<1$. $^{36}$

\footnotetext{
36 See Akinci (2017) for a review of the empirical evidence.
} 
Production is organized in firms. There is a continuum of firms of measure one in each of the tradable and non-tradable sectors. As we shall specify below, firms may need to borrow funds in the credit market in order to produce. We assume that all credit is intermediated by a continuum of competitive banks of measure one. Firms and banks are all owned by the economy's residents.

There is also a government that collects taxes from firms at $t=1$ in order to repay pre-existing public debt and provide subsidies.

\subsubsection{Tradable and non-tradable firms}

Firms are indexed by sector $T$ (tradable) and $N$ (non-tradable) and by an individual firm index $s \in[0,1]$. Each tradable firm $s$ is endowed at $t=0$ with $\omega_{T s}$ units of tradable good. The total tradable endowment at $t=0$ is thus given by

$$
\omega_{T}=\int_{0}^{1} \omega_{T s} \cdot d s .
$$

At $t=1$, the tradable good is produced competitively by final good producers that combine capital and labor according to the production function

$$
Y_{T}=K^{\alpha} \cdot L^{1-\alpha}
$$

where $L$ denotes labor and

$$
K=\left(\int_{0}^{1} k_{s}^{\frac{\varepsilon-1}{\varepsilon}} \cdot d s\right)^{\frac{\varepsilon}{\varepsilon-1}}
$$

is an aggregator of differentiated varieties of capital. We assume throughout that the elasticity of substitution $\varepsilon$ is high but finite.

Each variety of capital $s$ is produced by its corresponding tradable firm through investment. In particular, if tradable firm $s$ invests $i_{s}$ units of the tradable good at $t=0$ it produces

$$
k_{\mathrm{s}}=A \cdot i_{\mathrm{s}}
$$

units of capital $s$ at $t=1$.

Each resident is endowed with one unit of labor that is supplied inelastically in a competitive labor market, so that

$$
L=1
$$

In the non-tradable sector, firm $s$ is endowed with $\omega_{N s}$ units of the non-tradable good at $t=1$. The total non-tradable endowment at $t=1$ is thus given by

$$
\omega_{N}=\int_{0}^{1} \omega_{N s} \cdot d s .
$$

\subsubsection{Banks and financial markets}

Banks are indexed by sector $B$ and by an individual index $s \in[0,1]$. Banks start at $t=0$ with a pre-existing stock of public debt $b$ as assets and deposits by residents $d$ as liabilities. A fraction $\lambda$ of public debt is long-term and matures at $t=1$; the remaining fraction $1-\lambda$ is short-term and matures at $t=0$. All deposits are short-term and mature at $t=0$. We assume that banks start with more short-term liabilities than short-term assets, namely

$$
d>(1-\lambda) \cdot b
$$

At $t=0$, banks repay maturing deposits, take new deposits from residents and (some) tradable firms, extend loans to (other) tradable firms, receive the proceeds from maturing short-term public debt, and either sell or buy long-term public debt.

Banks can sell long-term public debt to the international financial market (IFM), although they cannot borrow directly from the IFM. We assume that the IFM buys an exogenous amount $x^{*}$ of long-term public debt. The variable $x^{*}$ is the key parameter of the model. We will interpret increases in $x^{*}$ as reflecting the exogenous inclusion of the country in sovereign debt indices. In the model, $x^{*}$ determines both sovereign debt inflows and total capital inflows since the private sector cannot borrow directly from the IFM. We assume that $x^{*} \leq \omega_{T}$.

\subsubsection{Public sector}

The government does not spend or impose any taxes at $t=0$. It just rolls over all maturing short-term public debt at the market interest rate $R$. 
At $t=1$, the government taxes the profits of tradable and non-tradable firms and banks. We assume that all profits are taxed at an exogenous rate $\tau$. Tax revenues are used to repay public debt and any remaining funds are transferred back as subsidies to a subset of "government-related" firms and banks. Total subsidies are thus given by

$$
\tau \cdot\left(\pi_{N}+\pi_{T}+\pi_{B}\right)-b \cdot[\lambda+(1-\lambda) \cdot R]
$$

where $\pi_{N}, \pi_{T}$, and $\pi_{B}$ respectively denote profits of non-tradable firms, tradable firms, and banks.

We assume that the same fraction $\theta$ of firms in each sector and of banks are government-related. Whether a firm is government-related is independent of its endowment. Finally, the subsidy is proportional to profits and it can be interpreted as a reduction in the tax rate. Letting $\sigma_{s}$ denote the subsidy rate of a government-related firm or bank, it follows that

$$
\sigma_{s}=\frac{1}{\theta} \cdot\left[\tau-\frac{b \cdot(\lambda+(1-\lambda) \cdot R)}{\pi_{N}+\pi_{T}+\pi_{B}}\right] .
$$

\subsection{Equilibrium}

We first analyze conditional equilibria at $t=1$ and then solve for the full equilibrium at $t=0$. At $t=1$, the prices of labor and capital are given by

$$
w=(1-\alpha) \cdot K^{\alpha} \text { and } q=\alpha \cdot K^{\alpha-1}
$$

The price of each variety of capital $s$ is proportional to the overall price of capital $q$ and decreasing in the relative supply $k_{s} / K$ of the variety:

$$
p_{s}=q \cdot\left(\frac{K}{k_{s}}\right)^{\frac{1}{\varepsilon}}
$$

Pre-tax profits of tradable firms, non-tradable firms and banks are respectively given by

$$
\begin{gathered}
\pi_{T S}=p_{s} \cdot k_{s}+\left(\omega_{T S}-i_{s}\right) \cdot R, \\
\pi_{N s}=p_{N} \cdot \omega_{N s}, \\
\pi_{B S}=\lambda \cdot b+[(1-\lambda) \cdot b-d] \cdot R,
\end{gathered}
$$

where $\omega_{T s}-i_{s}$ are net deposits by tradable firms $(1-\lambda) \cdot b-d$ are net lending by banks at $t=0$.

At $t=0$, tradable firms decide how much to invest taking $K$ and $R$ as given. Each tradable firm $s$ maximizes its market value

$$
V_{T s}=\left[\left(\frac{A \cdot p_{s}}{R}-1\right) \cdot i_{s}+\omega_{T s}\right] \cdot\left(1-\tau+\sigma_{s}\right) .
$$

by setting investment equal to

$$
i_{s}=\left(\frac{\varepsilon-1}{\varepsilon} \cdot \frac{\alpha \cdot A^{\frac{\varepsilon-1}{\varepsilon}}}{R}\right)^{\varepsilon} \cdot K^{1+\varepsilon \cdot(\alpha-1)} .
$$

It follows that $i_{s}=i$ for all tradable firms $s$, where $i$ also denotes total investment. Noting that $K=A \cdot i$, we can solve for investment demand $i$ as a function of the interest rate $R$ :

$$
i=\left(\frac{\varepsilon-1}{\varepsilon} \cdot \frac{\alpha \cdot A^{\alpha}}{R}\right)^{\frac{1}{1-\alpha}}
$$

Domestic residents roll over their deposits since they do not consume at $t=0$. Market clearing then requires that investment be equal to the endowment of tradable firms plus sovereign debt inflows $x^{*}$ :

$$
i=\omega_{T}+x^{*}
$$

Eqs. (5) and (6) jointly determine the equilibrium interest rate

$$
R=\frac{\varepsilon-1}{\varepsilon} \cdot \alpha \cdot A^{\alpha} \cdot\left(\omega_{T}+x^{*}\right)^{\alpha-1}
$$


Note that the equilibrium interest rate is lower than the marginal return of investment $\alpha \cdot A^{\alpha} \cdot i^{\alpha-1}$. The reason is that market power depresses investment and thus the demand for credit.

Given investment and the interest rate, market clearing and consumer optimization yield the price of non-tradable $\operatorname{goods}^{37}$

$$
P_{N}=\frac{\nu}{1-\nu} \cdot \omega_{N}^{-\frac{1}{\eta}} \cdot\left[A^{\alpha} \cdot\left(\omega_{T}+x^{*}\right)^{\alpha-1} \cdot\left(\omega_{T}+\left(1-\alpha \cdot \frac{\varepsilon-1}{\varepsilon}\right) \cdot x^{*}\right)\right]^{\frac{1}{\eta}} .
$$

We can now compute the equilibrium value of firms. In the tradable sector, the value of firm $s$ is given by

$$
V_{T S}=\left[\frac{1}{\varepsilon-1} \cdot\left(\omega_{T}+x^{*}\right)+\omega_{T S}\right] \cdot\left(1-\tau+\sigma_{s}\right),
$$

while the value of the average firm equals

$$
V_{T}=\left[\frac{\varepsilon}{\varepsilon-1} \cdot\left(\omega_{T}+\frac{x^{*}}{\varepsilon}\right)\right] \cdot\left[1-\frac{b \cdot(\lambda+(1-\lambda) \cdot R)}{\pi_{N}+\pi_{T}+\pi_{B}}\right]
$$

In the non-tradable sector, the value of firm $s$ is given by

$$
V_{N s}=\kappa_{N s} \cdot\left(A^{\alpha} \cdot\left(\omega_{T}+x^{*}\right)^{\alpha-1}\right)^{\frac{1-\eta}{\eta}} \cdot\left[\left(\omega_{T}+\left(1-\alpha \cdot \frac{\varepsilon-1}{\varepsilon}\right) \cdot x^{*}\right)\right]^{\frac{1}{\eta}} \cdot\left(1-\tau+\sigma_{s}\right),
$$

where $\kappa_{N s}=\frac{\nu}{1-\nu} \cdot \frac{\varepsilon-1}{\varepsilon} \cdot \omega_{N s} \cdot \omega_{N}^{-\frac{1}{\eta}}$, while the value of the average firm equals

$$
\begin{aligned}
V_{N} & =\kappa_{N} \cdot\left(A^{\alpha} \cdot\left(\omega_{T}+x^{*}\right)^{\alpha-1}\right)^{\frac{1-\eta}{\eta}} \cdot\left[\left(\omega_{T}+\left(1-\alpha \cdot \frac{\varepsilon-1}{\varepsilon}\right) \cdot x^{*}\right)\right]^{\frac{1}{\eta}} . \\
& \cdot\left[1-\frac{b \cdot(\lambda+(1-\lambda) \cdot R)}{\pi_{N}+\pi_{T}+\pi_{B}}\right],
\end{aligned}
$$

where $\kappa_{N}=\frac{\nu}{1-\nu} \cdot \frac{\varepsilon-1}{\varepsilon} \cdot \omega_{N}^{1-\frac{1}{\eta}}$.

Finally, the value of bank $s$ is given by

$$
V_{B s}=\frac{b \cdot \lambda-[d-b \cdot(1-\lambda)] \cdot R}{R} \cdot\left(1-\tau+\sigma_{s}\right),
$$

while the value of the average bank equals

$$
V_{B}=\left[\frac{\varepsilon}{\varepsilon-1} \cdot \frac{b \cdot \lambda \cdot\left(\omega_{T}+x^{*}\right)^{1-\alpha}}{\alpha \cdot A^{a}}-d+(1-\lambda) \cdot b\right] \cdot\left[1-\frac{b \cdot(\lambda+(1-\lambda) \cdot R)}{\pi_{N}+\pi_{T}+\pi_{B}}\right] .
$$

\subsection{Winners and losers from inflows}

How does an increase in sovereign debt inflows $x^{*}$ affect relative firm valuations? Using the valuations obtained above and after some straightforward algebra, the following results follow:

\subsubsection{Financial dependence}

Financially-dependent firms are those that borrow more. In the model only tradable firms participate in the financial market at $t=0$ and their borrowing is given by $i-\omega_{T s}$. Hence, tradable firms with lower endowment $\omega_{T s}$ are more financially dependent. The impact of sovereign debt inflows on the value of tradable firms

$$
\frac{1}{V_{T s}} \cdot \frac{d V_{T s}}{d x^{*}} \text { is decreasing in } \omega_{T s} .
$$

\footnotetext{
37 To derive this price, combine market the clearing conditions $C_{T}=Y_{T}-R \cdot x^{*}=A^{\alpha} \cdot\left(\omega_{T}+x^{*}\right)^{\alpha-1} \cdot\left(\omega_{T}+\left(1-\alpha \cdot \frac{\varepsilon-1}{\varepsilon}\right) \cdot x^{*}\right)$ and $C_{N}=\omega_{N}$, with the relative demand of non-tradable goods $\left(\frac{C_{N}}{C_{T}}\right)^{\frac{\eta}{\eta}}=\frac{\nu}{1-\nu} \cdot \frac{1}{P_{N}}$.
} 
The relative value of financially dependent firms increases with $x^{*}$. The reason is that reductions in the interest rate benefit borrowers.

\subsubsection{Tradable firms}

On average, the impact of sovereign debt inflows on the value of firms if smaller for tradable firms

$$
\frac{1}{V_{T}} \cdot \frac{d V_{T}}{d x^{*}}<\frac{1}{V_{N}} \cdot \frac{d V_{N}}{d x^{*}}
$$

This happens because sovereign debt inflows raise domestic consumption of tradables and, thus, lead to an increase in the relative price of the non-tradable good.

\subsubsection{Government-related firms}

Within each sector, sovereign debt inflows increase the relative value of government-related firms, namely

$$
\frac{1}{V_{S s}} \cdot \frac{d V_{S s}}{d x^{*}} \text { is increasing in } \sigma_{s}
$$

for sectors $S \in\{T, N, B\}$. This happens for two reasons. Sovereign debt inflows reduce the interest rate and allow the government to roll-over its debt at a lower cost, reducing government outlays. Also, capital inflows are expansionary and this increases tax revenues. Both effects raise the government subsidy and hence the relative valuation of government-related firms. ${ }^{38}$

\subsubsection{Financial firms}

The impact of sovereign debt inflows on the value of banks

$$
\frac{1}{V_{B}} \cdot \frac{d V_{B}}{d x^{*}} \text { is increasing in } \lambda \text { and } d \text {. }
$$

Sovereign debt inflows reduce the interest rate and raise the price of long-term bonds. The associated capital gains to banks are increasing in the share of long-term public debt $\lambda$. In addition, since bank leverage increases with $d$, so does the effect of these capital gains on stock returns. If these effects are strong enough the value of banks increases more than the value of tradable and non-tradable firms.

Overall, this section illustrates how a simple open-economy model with financial frictions can rationalize our empirical results. Namely, by increasing foreign demand for domestic public debt, inclusion in international indexes lead to capital inflows that reduce yields, appreciate the exchange rate, and have heterogenous effects across domestic firms.

\section{Conclusions}

This paper studies the effects of large local-currency sovereign debt inflows on domestic firms. To do so, it exploits six announcements of country inclusion into two major local-currency sovereign debt indexes. These announcements are not anticipated by investors and trigger large inflows from international investors seeking to replicate the index compositions.

Our results show that sovereign debt inflows significantly reduce local-currency sovereign bond yields and lead to an appreciation of the domestic currency. Also, they have sizable heterogeneous effects on domestic firms: while financial and government-related firms exhibit larger CARs following country inclusion announcements, tradable firms experience lower CARs. The former effect is more pronounced in countries that experience a larger decline in sovereign bond yields, whilst the latter effect is more pronounced in countries that experience a larger appreciation.

Our findings shed novel light on the channels through which capital inflows to sovereign debt markets affect domestic firms. They highlight that these inflows can have important effects on the domestic economy of recipient countries, favoring the growth of non-tradable firms at the expense of tradable firms, promoting the development of the financial sector, and relaxing the financial constraints faced by both the government and domestic firms.

\section{Appendix A. Appendix}

\section{A.1. International benchmark indexes for local currency sovereign bond markets}

International indexes are indexes which combine and track assets of different classes from different countries. Depending on the criteria used to select the countries to be included in the index, international indexes can be categorized in regional and global

\footnotetext{
38 The assumption that the government simply distributes its surplus as a handout among related firms is an extreme simplification. There are of course other ways in which a relaxation of the government resource constraint can benefit government-related firms (e.g., higher government demand for goods produced by these firms).
} 
indexes. The former track securities whose issuers are located in a given region - either geographically or based on the classification of countries in frontier, emerging, and developed markets -, while the latter track securities whose issuers are located in multiple regions. With the rise of financial globalization, international indexes have gained considerable importance, as they constitute the main benchmark for an increasingly large number of international investors.

Two of the main and most widely tracked international indexes for local currency-denominated government debt securities are the World Government Bond Index (WGBI) and J.P. Morgan Government Bond Index Emerging Markets (GBI-EM), which are constructed by Citigroup and J.P. Morgan, respectively. Both indexes represent key benchmarks for international investors in local currency sovereign debt markets. However, while the former is a global index which tracks the returns on sovereign bonds denominated in local currency issued by the governments of both developed and emerging countries, the latter is a regional index which solely focuses on emerging countries. ${ }^{39}$

As of 2016, the assets under management benchmarked against the WGBI were approximately 1.5 trillions U.S. dollars, and those benchmarked against the GBI-EM were approximately 200 billion U.S. dollars. Hence, when index providers change the composition of these two indexes, many international investors wishing to replicate the index composition rebalance their portfolios accordingly. Index rebalancings therefore trigger capital flows which, as shown in Pandolfi and Williams (2019), can have important price effects on the value of the local currency sovereign bonds involved in the rebalancing.

In this paper, in particular, we focus on some large rebalancings in these two indexes which are due to the inclusion of the following emerging countries: Colombia, Czech Republic, Mexico, Nigeria, Romania, and South Africa. During our sample period - which spans from 2010 to 2018 - Argentina was also included in the GBI-EM (in 2017). However, this event is not included in our sample as the inclusion was driven by the decision of the Argentinian government of removing the mandatory 120-days holding period for foreign capital, which was taken the day before the country inclusion announcement.

\section{A.2. Details on country inclusion events}

\section{A.2.1. Colombia}

On the 19th of March 2014, J.P. released a communication to investors which announced the inclusion of five Colombian treasury bonds (named TES) into the GBI-EM family of indexes. The index inclusion was planned to be implemented gradually between May and September 2014, bringing Colombian weight in the GBI-EM Global Diversified from 3.2\% to an estimated 8\% (as three TES were already included in the index before the inclusion episode). The document released by J.P. Morgan does not contain a time stamp, so we searched the web for news related to this event. The first news article we found was published by Reuters at 1:52 PM (Eastern Standard Time), which corresponds to 12:52 PM in Colombian time, when Colombian markets were still open. ${ }^{40}$ Hence, the first trading day for Colombia coincides with the announcement date and is set on the 19th of March 2014. As regards the drivers of the inclusion, J.P. Morgan states that this the "[...] result of improved transparency and accessibility for international investors in the local TES market [...]". Nevertheless, we could not find any relevant news about policy changes or changes in the functioning of Colombian sovereign debt market which might overlap with the inclusion announcement made by J.P. Morgan. The most significant regulatory change affecting Colombian sovereign debt market before the inclusion episode was a tax cut on foreigners investing in TES which occurred in January 2013, more than one year before the inclusion announcement.

\section{A.2.2. Czech Republic}

On the 22nd of February 2017, J.P. Morgan released a communication to investors which announced the inclusion of nine local-currency denominated Czech sovereign bonds into the GBI-EM family of indexes. The index inclusion was planned to be implemented gradually between April and June 2017, bringing Czech weight in the GBI-EM Global Diversified from 0\% to an estimated 3.3\%. The document was disseminated at 9:44 AM (Eastern Standard Time), which corresponds to 3:44 PM in Czech Republic time, when Czech markets were still open. Hence, the first trading day for Colombia coincides with the announcement date and is set on the 22nd of February 2017. The inclusion of Czech Republic in the J.P. Morgan GBI-EM was due to reclassification of the country from a developed to an emerging market, since: "Czech Republic's GNI per-capita levels falling below the Index Income Ceiling for three consecutive years". As a result, Czech sovereign bonds were excluded from developed markets indexes and included in the Emerging Markets ones. As the weight of Czech Republic in the index for developed countries was much smaller than that in the GBI-EM, the outflows due to the exclusion from the former were going to be much smaller than the inflows due to the inclusion in the latter. According to experts, the transition should have brought between 3 and 6 billion U.S. dollar inflows to the country. ${ }^{41}$

\footnotetext{
39 As a result, the sovereign debt bonds of some emerging countries are included in both indexes. However, given that the average market capitalization of the securities in the WGBI is much larger than that in the GBI-EM, the weight of emerging countries in the former is typically much lower than the weight they have in the latter. For instance, Mexican local currency sovereign bonds account for about $10 \%$ of the GBI-EM, while they account for less than $1 \%$ of the WGBI.

${ }^{40}$ Source: Reuters. https://www.reuters.com/article/colombia-jpmorgan-debt/j-p-morgan-to-boost-colombia-bond-weighting-peso-up-most-in-6-monthsidUSL2NOMG12I20140319 (Retrieved on May 6, 2020).

${ }^{41}$ Source: Pensions\&Investments Online. https://www.pionline.com/article/20170428/ONLINE/170429837/j-p-morgan-drops-czech-republic-bonds-to-emergingmarkets-indexes-inflows-expected (Retrieved on May 6, 2020).
} 


\section{A.2.3. Mexico}

On the 31st of March 2010, Citigroup announced that Mexican sovereign bonds were eligible for inclusion in the WGBI, with an estimated weight equal to $0.65 \%$. We searched the web for news related to this event. The first news article we found was published by Reuters at 12:41 PM (Eastern Standard Time), which corresponds to 11:41 AM in Mexican time, when Mexican markets were still open. ${ }^{42}$ Hence, the first trading day for Mexico coincides with the announcement date and is set on the 31st of March 2010. The eligibility announcement stated that: "If Mexico continues to meet all WGBI criteria for three consecutive months starting with the April 2010 index profile, it will become the first Latin American and the 24th government bond market to enter the WGBI. Entry would be effective October 2010". The criteria refer to the size and ratings of the Mexican sovereign bonds, and their accessibility to foreign investors. Several news articles highlighted that Mexico already fulfilled the size and ratings requirements and that during the past year the government of Mexico improved the liquidity of the government bond market by issuing 30-year bonds, selling syndicated debt to foreigners and creating a primary dealers program. As a result, Mexico was eventually included in the WGBI in October 2010.

\section{A.2.4. Nigeria}

On the 14th of August 2012, J.P. Morgan released a communication to investors which announced the inclusion of localcurrency denominated Nigerian sovereign bonds (FGN) maturing in 2014, 2019 and 2022, into the GBI-EM family of indexes. The index inclusion was planned to be implemented gradually between October and December 2012, bringing Nigerian weight in the GBI-EM Global Diversified from $0 \%$ to an estimated $0.59 \%$ (the estimate was later revised to $0.72 \%$ ). The document released by J.P. Morgan does not contain a time stamp, so we searched the web for news related to this event. The first news article we found was published by Reuters on the 15th of August at 12:46 PM (Eastern Standard Time), which corresponds to 5:46 PM in Nigerian time, when Nigerian markets had already closed. ${ }^{43}$ Due to the one-day delay between the communication by J.P. Morgan and the diffusion of the news, we assume that the latest date is the one in which the information was effectively received by international investors. In fact, we do observe an increase in transaction of local currency sovereign bonds on the day following the dissemination of the Reuters' article. Hence, we set the first trading day after the announcement on the 16th of August 2012. As regards the drivers of the inclusion, J.P. Morgan stated that this is the result of the improved liquidity of the Nigerian sovereign debt market, in large part due to the removal of the mandatory one-year holding period for foreign capital occurred in June 2011, more than one year before the inclusion announcement.

\section{A.2.5. Romania}

On the 16th of January 2013, J.P. Morgan released a communication to investors which announced the inclusion of localcurrency denominated Romanian sovereign bonds (RON) maturing in 2015, 2016 and 2017, into the GBI-EM family of indexes. The index inclusion was planned to be implemented gradually between March and May 2013, bringing Romanian weight in the GBI-EM Global Diversified from $0 \%$ to an estimated $0.54 \%$ (the estimate was later revised to $0.87 \%$ ). The document released by J.P. Morgan does not contain a time stamp, so we searched the web for news related to this event. The first news article we found was published by Reuters on the 16th of January, according to which J.P. Morgan had announced the inclusion overnight. ${ }^{44}$ We therefore set the first trading day after the announcement on the 16th of January 2013. As regards the drivers of the inclusion, J.P. Morgan stated that this was the result of the improved liquidity of the Romanian sovereign debt market occurred in the 18 months preceding the announcement.

\section{A.2.6. South Africa}

On the 16th of April 2012, Citigroup announced that 11 Southern African sovereign bonds were eligible for inclusion in the WGBI. The document released by Citigroup does not contain a time stamp, so we searched the web for news related to this event. The first news article we found was published on the 17th of April by Reuters at 07:05 AM (Eastern Standard Time), which corresponds to 1:05 PM in the time of South Africa, when markets were still open ${ }^{45}$ Hence, we set the first trading day after the announcement on the 17th of April 2012. The eligibility announcement stated that: "If South Africa continues to meet all WGBI criteria with the May and June 2012 profiles, it will become the first African government bond market to be included in the WGBI". The criteria refer to the size and ratings of the domestic sovereign bonds, and their accessibility to foreign investors. South Africa already fulfilled the size and ratings requirements at the time of the announcement. As for the accessibility to foreign investors, it most likely improved in the year preceding the inclusion, but we could not find more detailed information.

\footnotetext{
42 Source: Reuters. https://www.reuters.com/article/mexico-index/update-1-citi-says-mexico-eligible-for-wgbi-bond-index-idUSN3121335820100331 (Retrieved on May 6, 2020).

43 Source: Reuters. https://in.reuters.com/article/us-nigeria-debt-idINBRE87E0TF20120815 (Retrieved on May 6, 2020).

44 Source: Reuters. https://www.reuters.com/article/romania-debt/jp-morgan-gives-fresh-impetus-to-romania-debt-idUSL6N0AL7IY20130116 (Retrieved on May 6, 2020).

45 Source: Reuters. https://af.reuters.com/article/southAfricaNews/idAFL6E8FH3YH20120417 (Retrieved on May 6, 2020).
} 


\section{A.3. Additional figures $\mathcal{E}$ tables}

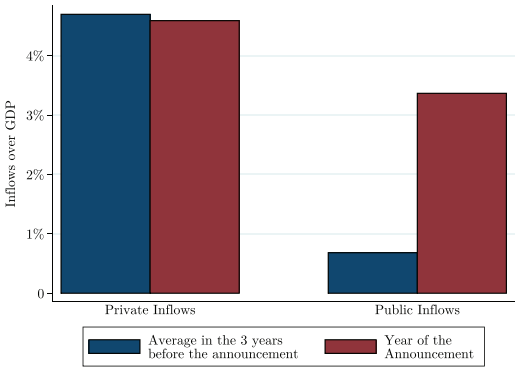

Colombia

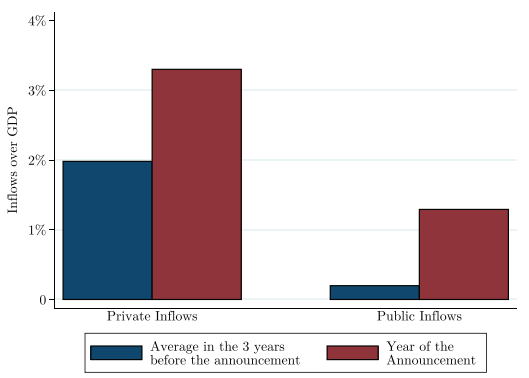

Nigeria

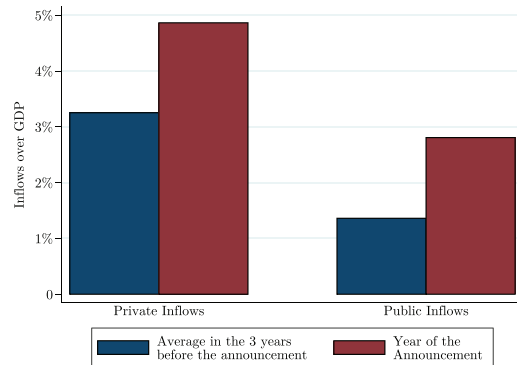

Czech Republic

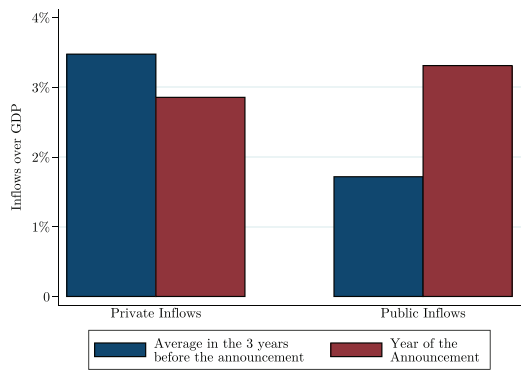

Romania

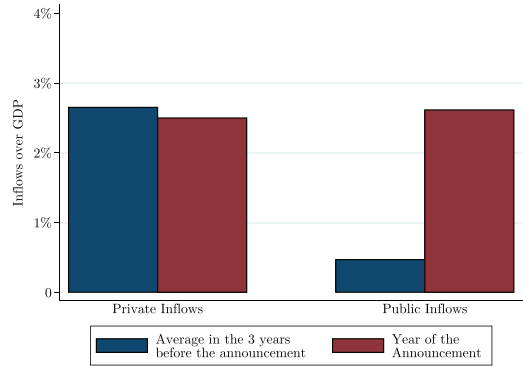

Mexico

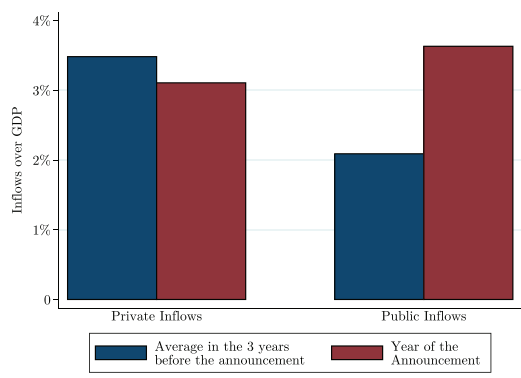

South Africa

Fig. A1. Balance of Payments: Private vs. Public Inflows in Each Country. This figure depicts the private and the public net inflows to Colombia, Czech Republic, Mexico, Nigeria, Romania and South Africa in the year of the announcement of each country's inclusion into the corresponding index vs. the average of public and private inflows to these countries in the three years before the announcement episodes. Private inflows are the sum of foreign direct investments, portfolio equity net inflows and private debt net inflows. Public inflows are net inflows to the countries' sovereign debt markets. Both are in U.S. dollars and are normalized by the GDP of each country. Inflows are reported separately for each of the countries in our sample. Data is from the IMF Balance of Payments Statistics and IMF WEO.

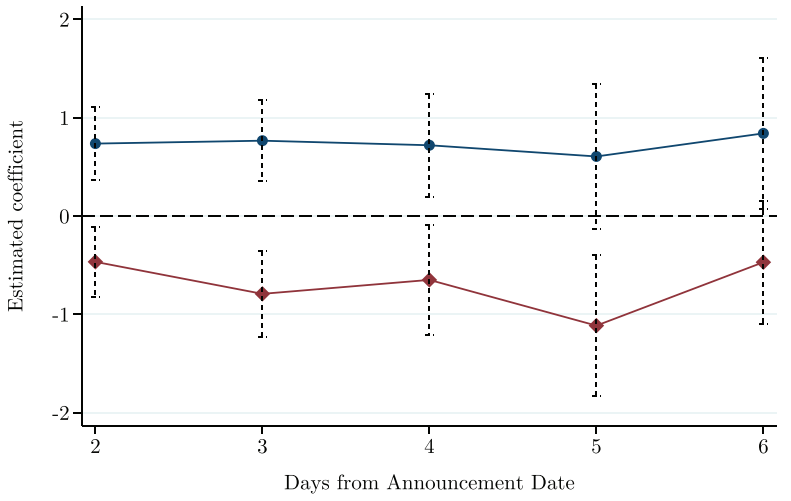

$\longrightarrow$ Gvt\&Fin $\longrightarrow$ Tradable $\quad$ r------i $90 \%$ C.I.

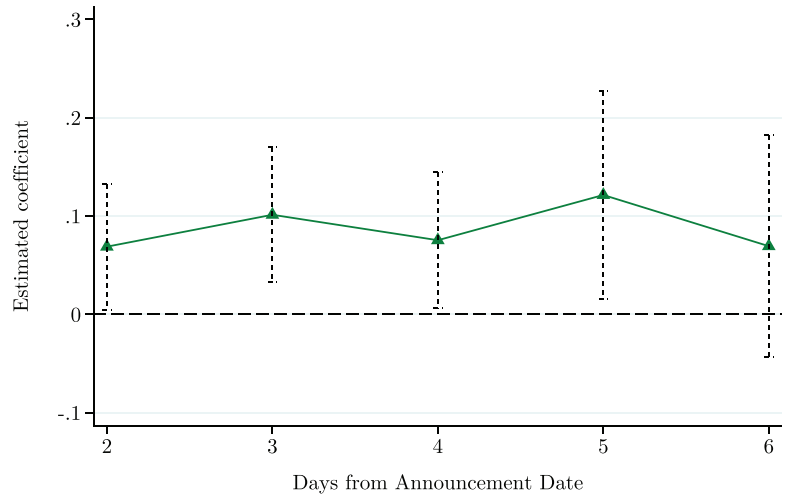

External Financial Dependance

Fig. A2. Alternative time windows. This figure depicts the estimated coefficients of $\mathbb{1}($ Govt \& Fin), $\mathbb{1}($ Tradable), and $E F D$ in 5 regressions of the form: CAR $(\text { Govt \& Fin })_{i}+\beta_{2} \mathbb{1}(\text { Tradable })_{i}+\beta_{3} E F D_{i}+\varepsilon_{i}$, where $C A R_{i}$ is the cumulative abnormal return of firm $i$ in the $t$ days following the announcement episode, with $t \in[2,6]$. CARs are computed using a 1 -factor model where the only risk factor is the return of the MSCI Emerging Markets Index. $\mathbb{1}($ Govt \& Fin) is a dummy variable which equals 1 for government-related and financial companies, $\mathbb{1}$ (Tradable) is a dummy which equals 1 for firms operating in tradable sectors, and EFD is a measure of external financial dependance computed at the industry-level. In each regression, observations in the top and the bottom percentile of the countryspecific distribution of cumulative abnormal returns are excluded. 
Table A1

Government ownership and government demand.

\begin{tabular}{|c|c|c|c|c|}
\hline \multicolumn{5}{|c|}{ 2-Day Cumulative Abnormal Returns after Announcement Dates } \\
\hline & Demeaned Returns & 1-Factor Model & 2-Factor Model & 5-Factor Model \\
\hline Financial & $\begin{array}{l}0.545^{*} \\
(0.289)\end{array}$ & $\begin{array}{l}0.628^{* *} \\
(0.284)\end{array}$ & $\begin{array}{l}0.632^{* *} \\
(0.279)\end{array}$ & $\begin{array}{l}0.588^{*} \\
(0.301)\end{array}$ \\
\hline Gvt Owned & $\begin{array}{l}0.661 \\
(0.440)\end{array}$ & $\begin{array}{l}0.550 \\
(0.478)\end{array}$ & $\begin{array}{l}0.608 \\
(0.468)\end{array}$ & $\begin{array}{l}0.591 \\
(0.451)\end{array}$ \\
\hline Gvt Demand & $\begin{array}{l}0.512^{* *} \\
(0.245)\end{array}$ & $\begin{array}{l}0.516^{* *} \\
(0.249)\end{array}$ & $\begin{array}{l}0.549^{* *} \\
(0.254)\end{array}$ & $\begin{array}{l}0.626^{* *} \\
(0.267)\end{array}$ \\
\hline Tradable & $\begin{array}{l}-0.508^{* *} \\
(0.218)\end{array}$ & $\begin{array}{l}-0.465^{* *} \\
(0.221)\end{array}$ & $\begin{array}{l}-0.488^{* *} \\
(0.220)\end{array}$ & $\begin{array}{l}-0.441^{*} \\
(0.236)\end{array}$ \\
\hline External Financial Dependance & $\begin{array}{l}0.071^{*} \\
(0.041)\end{array}$ & $\begin{array}{l}0.069^{*} \\
(0.041)\end{array}$ & $\begin{array}{l}0.074^{*} \\
(0.041)\end{array}$ & $\begin{array}{l}0.073^{*} \\
(0.043)\end{array}$ \\
\hline Number of Countries & 6 & 6 & 6 & 6 \\
\hline Observations & 857 & 857 & 857 & 857 \\
\hline $\mathrm{R}^{2}-\mathrm{n}-1$ & 0.02 & 0.02 & 0.02 & 0.02 \\
\hline
\end{tabular}

This table reports the OLS coefficients of a regression where the dependent variable is the CAR of each firm in the 2 days following the announcement of each country's inclusion in the corresponding index. The explanatory variables are: Financial, which is an indicator variable that is equal to 1 for financial firms; Gvt Owned, which is an indicator variable that is equal to 1 for firms which are partially owned by the domestic government; Gvt Demand, which is an indicator variable that is equal to 1 for firms which are related to the domestic government because of their business activity; Tradable, which is an indicator variable equal to for firms in tradable industries (according to the classification in Mian and Sufi (2014)); and External Financial Dependance, which is a measure of firms' dependance on external financing sources, computed following Rajan and Zingales (1998). The table reports also the difference between the estimated coefficient on Financial and that on Tradable, as well as the difference between the estimated coefficients on Government-Related and that on Tradable. CARs in the first column (the demeaned returns) are computed as the the cumulated differences between the daily returns and the average daily return in the year preceding the announcement. CARs in columns 2 to 4 are computed using three different factor models. The only risk factor in the 1 -factor model is the return of the MSCI Emerging Markets Index; the two risk factors in the 2-factor model are the return of the MSCI Emerging Markets Index and the return of the MSCI World Index; the 5factor model include these two risk factors plus small minus big (SMB), high minus low (HML), and momentum (WML) factors. Observations in the top and the bottom percentile of the country-specific distribution of 2-day cumulative abnormal returns are excluded. Standard errors in parenthesis are clustered at the country-by-industry level. ${ }^{*},{ }^{* *},{ }^{* * *}$, denote significance at the $10 \%, 5 \%$, and $1 \%$ confidence level, respectively.

Table A2

Robustness tests.

\begin{tabular}{|c|c|c|c|c|}
\hline \multicolumn{5}{|c|}{ Panel A: No companies with zero returns in $(-10,10)$} \\
\hline & Demeaned Returns & 1-Factor Model & 2-Factor Model & 5-Factor Model \\
\hline Financial & $\begin{array}{l}0.537 \\
(0.451)\end{array}$ & $\begin{array}{l}0.703 \\
(0.448)\end{array}$ & $\begin{array}{l}0.682 \\
(0.430)\end{array}$ & $\begin{array}{l}0.678 \\
(0.474)\end{array}$ \\
\hline Government-Related & $\begin{array}{l}0.692^{* *} \\
(0.350)\end{array}$ & $\begin{array}{l}0.628^{*} \\
(0.362)\end{array}$ & $\begin{array}{l}0.672^{*} \\
(0.353)\end{array}$ & $\begin{array}{l}0.694^{*} \\
(0.357)\end{array}$ \\
\hline Tradable & $\begin{array}{l}-0.878^{* * *} \\
(0.313)\end{array}$ & $\begin{array}{l}-0.802^{* *} \\
(0.316)\end{array}$ & $\begin{array}{l}-0.844^{* * *} \\
(0.315)\end{array}$ & $\begin{array}{l}-0.816^{* *} \\
(0.332)\end{array}$ \\
\hline External Financial Dependance & $\begin{array}{l}0.083 \\
(0.063) \\
\end{array}$ & $\begin{array}{l}0.084 \\
(0.063)\end{array}$ & $\begin{array}{l}0.089 \\
(0.061)\end{array}$ & $\begin{array}{l}0.093 \\
(0.064)\end{array}$ \\
\hline Financial - Tradable & $\begin{array}{l}1.42^{* * * *} \\
(0.48)\end{array}$ & $\begin{array}{l}1.50^{* * *} \\
(0.47)\end{array}$ & $\begin{array}{l}1.53^{* * * *} \\
(0.44)\end{array}$ & $\begin{array}{l}1.49^{* * *} \\
(0.49)\end{array}$ \\
\hline Govt-Related - Tradable & $\begin{array}{l}1.57^{* * * *} \\
(0.48)\end{array}$ & $\begin{array}{l}1.43^{* * * *} \\
(0.49)\end{array}$ & $\begin{array}{l}1.52^{* * *} \\
(0.48)\end{array}$ & $\begin{array}{l}1.51^{\text {**** }} \\
(0.49)\end{array}$ \\
\hline Observations & 565 & 565 & 565 & 565 \\
\hline $\mathrm{R}^{2}$ & 0.03 & 0.03 & 0.03 & 0.03 \\
\hline \multicolumn{5}{|l|}{ Panel B: No multi-stock companies } \\
\hline & Detrended Returns & 1-Factor Model & 2-Factor Model & 5-Factor Model \\
\hline Financial & $\begin{array}{l}0.444 \\
(0.388)\end{array}$ & $\begin{array}{l}0.543 \\
(0.387)\end{array}$ & $\begin{array}{l}0.526 \\
(0.370)\end{array}$ & $\begin{array}{l}0.545 \\
(0.408)\end{array}$ \\
\hline Government-Related & $\begin{array}{l}0.703^{* *} \\
(0.307)\end{array}$ & $\begin{array}{l}0.622^{*} \\
(0.322)\end{array}$ & $\begin{array}{l}0.656^{* *} \\
(0.313)\end{array}$ & $\begin{array}{l}0.676^{* *} \\
(0.310)\end{array}$ \\
\hline Tradable & $\begin{array}{l}-0.715^{* * *} \\
(0.262)\end{array}$ & $\begin{array}{l}-0.668^{* *} \\
(0.265)\end{array}$ & $\begin{array}{l}-0.688^{* * *} \\
(0.264)\end{array}$ & $\begin{array}{l}-0.664^{* *} \\
(0.279)\end{array}$ \\
\hline External Financial Dependance & $\begin{array}{l}0.067 \\
(0.051)\end{array}$ & $\begin{array}{l}0.064 \\
(0.051)\end{array}$ & $\begin{array}{l}0.068 \\
(0.050)\end{array}$ & $\begin{array}{l}0.073 \\
(0.052)\end{array}$ \\
\hline
\end{tabular}


Table A2 (continued)

\begin{tabular}{|c|c|c|c|c|}
\hline \multicolumn{5}{|l|}{ Panel B: No multi-stock companies } \\
\hline & Detrended Returns & 1-Factor Model & 2-Factor Model & 5-Factor Model \\
\hline \multirow[t]{2}{*}{ Financial - Tradable } & $1.16^{* * *}$ & $1.21^{* * *}$ & $1.21^{* * *}$ & $1.21^{* * *}$ \\
\hline & $(0.41)$ & $(0.40)$ & $(0.38)$ & $(0.41)$ \\
\hline \multirow[t]{2}{*}{ Govt-Related - Tradable } & $1.42^{* * *}$ & $1.29^{* * *}$ & $1.34^{* * *}$ & $1.34^{* * *}$ \\
\hline & $(0.40)$ & $(0.42)$ & $(0.41)$ & $(0.41)$ \\
\hline Observations & 652 & 652 & 652 & 652 \\
\hline $\mathrm{R}^{2}$ & 0.03 & 0.02 & 0.03 & 0.02 \\
\hline \multicolumn{5}{|c|}{ Panel C: Without Nigeria and Czech Republic } \\
\hline & Demeaned Returns & 1-Factor Model & 2-Factor Model & 5-Factor Model \\
\hline \multirow{2}{*}{ Financial } & 0.413 & 0.534 & 0.519 & 0.507 \\
\hline & $(0.364)$ & $(0.363)$ & $(0.348)$ & $(0.383)$ \\
\hline \multirow[t]{2}{*}{ Government-Related } & $0.633^{* *}$ & $0.566^{*}$ & $0.598^{*}$ & $0.625^{* *}$ \\
\hline & $(0.305)$ & $(0.316)$ & $(0.308)$ & $(0.310)$ \\
\hline \multirow[t]{2}{*}{ Tradable } & $-0.716^{* * *}$ & $-0.661^{* *}$ & $-0.686^{* * *}$ & $-0.661^{* *}$ \\
\hline & $(0.258)$ & $(0.261)$ & $(0.260)$ & $(0.274)$ \\
\hline \multirow[t]{2}{*}{ External Financial Dependance } & 0.066 & 0.064 & 0.069 & 0.072 \\
\hline & $(0.050)$ & $(0.050)$ & $(0.049)$ & $(0.051)$ \\
\hline \multirow[t]{2}{*}{ Financial - Tradable } & $1.13^{* * *}$ & $1.20^{* * *}$ & $1.20^{* * *}$ & $1.17^{* * *}$ \\
\hline & $(0.39)$ & $(0.38)$ & $(0.36)$ & $(0.39)$ \\
\hline \multirow[t]{2}{*}{ Govt-Related - Tradable } & $1.35^{* * *}$ & $1.23^{* * *}$ & $1.28^{* * *}$ & $1.29^{* * *}$ \\
\hline & $(0.40)$ & $(0.41)$ & $(0.40)$ & $(0.41)$ \\
\hline Observations & 680 & 680 & 680 & 680 \\
\hline $\mathrm{R}^{2}$ & 0.03 & 0.02 & 0.02 & 0.02 \\
\hline
\end{tabular}

This table reports the OLS coefficients of a regression where the dependent variable is the CAR of each firm in the 2 days following the announcement of each country's inclusion in the corresponding index. In Panel A, we exclude firms whose price never changes in the 20 trading days around the announcement date. In Panel B, we reduce the weight of firms issuing more than one stock, by considering for each of these companies only the average 2-day CAR of the company's traded securities. In Panel C, we exclude Nigeria and Czech Republic. In all panels, the explanatory variables are: Financial, which is an indicator variable that is equal to 1 for financial firms; Government-Related, which is an indicator variable that is equal to 1 for government-related firms; Tradable, which is an indicator variable equal to for firms in tradable industries (according to the classification in Mian and Sufi (2014)); and External Financial Dependance, which is a measure of firms' dependance on external financing sources, computed following Rajan and Zingales (1998). The table reports also the difference between the estimated coefficient on Financial and that on Tradable, as well as the difference between the estimated coefficients on Government-Related and that on Tradable. CARs in the first column (the demeaned returns) are computed as the the cumulated differences between the daily returns and the average daily return in the year preceding the announcement. CARs in columns 2 to 4 are computed using three different factor models. The only risk factor in the 1 -factor model is the return of the MSCI Emerging Markets Index; the two risk factors in the 2-factor model are the return of the MSCI Emerging Markets Index and the return of the MSCI World Index; the 5-factor model include these two risk factors plus small minus big (SMB), high minus low (HML), and momentum (WML) factors. Observations in the top and the bottom percentile of the country-specific distribution of 2-day cumulative abnormal returns are excluded. Standard errors in parenthesis are clustered at the country-by-industry level. *, ${ }^{* *},{ }^{* * *}$, denote significance at the $10 \%, 5 \%$, and $1 \%$ confidence level, respectively.

Table A3

Main results with Country FE.

\begin{tabular}{|c|c|c|c|c|}
\hline \multicolumn{5}{|c|}{ 2-Day Cumulative Abnormal Returns after Announcement Dates } \\
\hline & Demeaned Returns & 1-Factor Model & 2-Factor Model & 5-Factor Model \\
\hline \multirow[t]{2}{*}{ Financial } & $0.533^{*}$ & $0.595^{* *}$ & $0.574^{* *}$ & $0.579 *$ \\
\hline & $(0.284)$ & $(0.279)$ & $(0.274)$ & $(0.300)$ \\
\hline \multirow[t]{2}{*}{ Government-Related } & $0.576^{* *}$ & $0.523^{* *}$ & $0.579^{* *}$ & $0.641^{* *}$ \\
\hline & $(0.241)$ & $(0.245)$ & $(0.244)$ & $(0.248)$ \\
\hline \multirow{2}{*}{ Tradable } & $-0.419^{*}$ & $-0.394^{*}$ & $-0.420^{*}$ & -0.365 \\
\hline & $(0.226)$ & $(0.226)$ & $(0.227)$ & $(0.248)$ \\
\hline \multirow[t]{2}{*}{ External Financial Dependance } & $0.075^{*}$ & $0.072 *$ & $0.076^{*}$ & $0.075^{*}$ \\
\hline & $(0.041)$ & $(0.042)$ & $(0.041)$ & $(0.043)$ \\
\hline Country FE & Yes & Yes & Yes & Yes \\
\hline \multirow[t]{2}{*}{ Financial - Tradable } & $0.95^{* * *}$ & $0.99 * * *$ & $0.99^{* * *}$ & $0.94^{* * *}$ \\
\hline & $(0.30)$ & $(0.29)$ & $(0.28)$ & $(0.31)$ \\
\hline \multirow[t]{2}{*}{ Govt-Related - Tradable } & $0.99^{* * *}$ & $0.92^{* * *}$ & $1.00^{* * *}$ & $1.01^{* * *}$ \\
\hline & $(0.32)$ & $(0.33)$ & $(0.33)$ & $(0.34)$ \\
\hline
\end{tabular}


Table A3 (continued)

\begin{tabular}{llll}
\hline 2-Day Cumulative Abnormal Returns after Announcement Dates & & \\
\hline & Demeaned Returns & 1-Factor Model & 2-Factor Model \\
\hline Number of Countries & 6 & 6 & 6 \\
Observations & 857 & 857 & 6 \\
$\mathrm{R}^{2}$ & 0.04 & 0.04 & 857 \\
\hline
\end{tabular}

This table reports the OLS coefficients of a regression where the dependent variable is the CAR of each firm in the 2 days following the announcement of each country's inclusion in the corresponding index. The explanatory variables are: Financial, which is an indicator variable that is equal to 1 for financial firms; Government-Related, which is an indicator variable that is equal to 1 for government-related firms; Tradable, which is an indicator variable equal to for firms in tradable industries (according to the classification in Mian and Sufi (2014)); and External Financial Dependance, which is a measure of firms' dependance on external financing sources, computed following Rajan and Zingales (1998). All regressions include country fixed effects. The table reports also the difference between the estimated coefficient on Financial and that on Tradable, as well as the difference between the estimated coefficients on Government-Related and that on Tradable. CARs in the first column (the demeaned returns) are computed as the the cumulated differences between the daily returns and the average daily return in the year preceding the announcement. CARs in columns 2 to 4 are computed using three different factor models. The only risk factor in the 1-factor model is the return of the MSCI Emerging Markets Index; the two risk factors in the 2-factor model are the return of the MSCI Emerging Markets Index and the return of the MSCI World Index; the 5-factor model include these two risk factors plus small minus big (SMB), high minus low (HML), and momentum (WML) factors. Observations in the top and the bottom percentile of the country-specific distribution of 2-day cumulative abnormal returns are excluded. Standard errors in parenthesis are clustered at the country-by-industry level. *, ${ }^{* *},{ }^{* * *}$, denote significance at the $10 \%, 5 \%$, and $1 \%$ confidence level, respectively.

Table A4

Placebo tests.

\begin{tabular}{|c|c|c|c|c|}
\hline \multicolumn{5}{|c|}{ Panel A: 2-Day Cumulative Abnormal Returns (2 Days before announcement) } \\
\hline & Demeaned Returns & 1-Factor Model & 2-Factor Model & 5-Factor Model \\
\hline Financial & $\begin{array}{l}0.264 \\
(0.250)\end{array}$ & $\begin{array}{l}0.254 \\
(0.263)\end{array}$ & $\begin{array}{l}0.248 \\
(0.264)\end{array}$ & $\begin{array}{l}0.219 \\
(0.258)\end{array}$ \\
\hline Government-Related & $\begin{array}{l}-0.160 \\
(0.232)\end{array}$ & $\begin{array}{l}-0.227 \\
(0.245)\end{array}$ & $\begin{array}{l}-0.237 \\
(0.249)\end{array}$ & $\begin{array}{l}-0.227 \\
(0.242)\end{array}$ \\
\hline Tradable & $\begin{array}{l}0.402^{*} \\
(0.225)\end{array}$ & $\begin{array}{l}0.343 \\
(0.224)\end{array}$ & $\begin{array}{l}0.337 \\
(0.223)\end{array}$ & $\begin{array}{l}0.349 \\
(0.226)\end{array}$ \\
\hline External Financial Dependance & $\begin{array}{l}-0.041 \\
(0.038)\end{array}$ & $\begin{array}{l}-0.044 \\
(0.039) \\
\end{array}$ & $\begin{array}{l}-0.046 \\
(0.039)\end{array}$ & $\begin{array}{l}-0.047 \\
(0.039)\end{array}$ \\
\hline Number of Countries & 6 & 6 & 6 & 6 \\
\hline Observations & 857 & 857 & 857 & 857 \\
\hline $\mathrm{R}^{2}$ & 0.01 & 0.01 & 0.01 & 0.01 \\
\hline
\end{tabular}

Panel B: 2-Day Cumulative Abnormal Returns (2 Days before announcement)

\begin{tabular}{|c|c|c|c|c|c|c|c|c|}
\hline \multirow[b]{2}{*}{$\Delta$ Yield $\times$ Govt $\&$ Fin } & \multicolumn{2}{|c|}{ Demeaned Returns } & \multicolumn{2}{|c|}{ 1-Factor Model } & \multicolumn{2}{|c|}{ 2-Factor Model } & \multicolumn{2}{|c|}{ 5-Factor Model } \\
\hline & $\begin{array}{l}0.003 \\
(0.005)\end{array}$ & $\begin{array}{l}0.001 \\
(0.005)\end{array}$ & $\begin{array}{l}0.002 \\
(0.005)\end{array}$ & $\begin{array}{l}-0.000 \\
(0.005)\end{array}$ & $\begin{array}{l}0.002 \\
(0.005)\end{array}$ & $\begin{array}{c}-0.000 \\
(0.005)\end{array}$ & $\begin{array}{l}0.002 \\
(0.005)\end{array}$ & $\begin{array}{l}-0.001 \\
(0.005)\end{array}$ \\
\hline$\% \Delta$ ExchRate $\times$ Tradable & $\begin{array}{l}0.118 \\
(0.149)\end{array}$ & $\begin{array}{l}0.158 \\
(0.155)\end{array}$ & $\begin{array}{l}0.068 \\
(0.150)\end{array}$ & $\begin{array}{l}0.110 \\
(0.156)\end{array}$ & $\begin{array}{l}0.067 \\
(0.151)\end{array}$ & $\begin{array}{l}0.112 \\
(0.156)\end{array}$ & $\begin{array}{l}0.068 \\
(0.152)\end{array}$ & $\begin{array}{l}0.112 \\
(0.157)\end{array}$ \\
\hline External Financial Dependance & & $\begin{array}{l}-0.048 \\
(0.036)\end{array}$ & & $\begin{array}{l}-0.052 \\
(0.037)\end{array}$ & & $\begin{array}{l}-0.054 \\
(0.038)\end{array}$ & & $\begin{array}{l}-0.053 \\
(0.037)\end{array}$ \\
\hline Country FE & Yes & Yes & Yes & Yes & Yes & Yes & Yes & Yes \\
\hline Number of Countries & 6 & 6 & 6 & 6 & 6 & 6 & 6 & 6 \\
\hline Observations & 861 & 857 & 861 & 857 & 861 & 857 & 861 & 857 \\
\hline $\mathrm{R}^{2}$ & 0.01 & 0.01 & 0.01 & 0.01 & 0.00 & 0.01 & 0.01 & 0.01 \\
\hline
\end{tabular}

This table reports the OLS coefficients of a regression where the dependent variable is the CAR of each firm over the interval [t-3,t-2], where $t$ is the first trading day after the announcement of each country's inclusion in the corresponding index. In Panel A, the explanatory variables are: Financial, which is an indicator variable that is equal to 1 for financial firms; Government-Related, which is an indicator variable that is equal to 1 for government-related firms; Tradable, which is an indicator variable equal to for firms in tradable industries (according to the classification in Mian and Sufi (2014)); and External Financial Dependance, which is a measure of firms' dependance on external financing sources, computed following Rajan and Zingales (1998). In Panel B, the explanatory variables are: $\Delta$ Yield $\times$ Govt \& Fin, which is the product of indicator variable that is equal to 1 for financial and government-related firms, and the 2-day change in the 5-year local currency government bond yield, in basis points; \% $\Delta$ ExchRate $\times$ Tradable, which is the product of Tradable and the 2-day percentage change in the exchange rate (computed as the difference in the log of the exchange rate) in percentage points; External Financial Dependance; and country fixed effects. CARs in the first column (the demeaned returns) are computed as the the cumulated differences between the daily returns and the average daily return in the year preceding the announcement. CARs in columns 2 to 4 are computed using three different factor models. The only risk factor in the 1 -factor model is the return of the MSCI Emerging Markets Index; the two risk factors in the 2-factor model are the return of the MSCl Emerging Markets Index and the return of the MSCI World Index; the 5-factor model include these two risk factors plus small minus big (SMB), high minus low (HML), and momentum (WML) factors. Observations in the top and the bottom percentile of the country-specific distribution of 2-day cumulative abnormal returns are excluded. Standard errors in parenthesis are clustered at the country-by-industry level. ${ }^{*},{ }^{* *},{ }^{* * *}$, denote significance at the $10 \%, 5 \%$, and $1 \%$ confidence level, respectively. 
Table A5

Main results controlling for betas.

\begin{tabular}{|c|c|c|c|c|}
\hline \multicolumn{5}{|c|}{ 2-Day Cumulative Abnormal Returns after Announcement Dates } \\
\hline & 1-Factor Model & 1-Factor Model & 2-Factor Model & 2-Factor Model \\
\hline Financial & $\begin{array}{l}0.613^{* *} \\
(0.285)\end{array}$ & $\begin{array}{l}0.610^{* *} \\
(0.285)\end{array}$ & $\begin{array}{l}0.614^{* *} \\
(0.280)\end{array}$ & $\begin{array}{l}0.583^{* *} \\
(0.282)\end{array}$ \\
\hline Government-Related & $\begin{array}{l}0.598^{* *} \\
(0.249)\end{array}$ & $\begin{array}{l}0.588^{* *} \\
(0.251)\end{array}$ & $\begin{array}{l}0.656^{* * *} \\
(0.247)\end{array}$ & $\begin{array}{l}0.624^{* *} \\
(0.247)\end{array}$ \\
\hline Tradable & $\begin{array}{l}-0.472^{* *} \\
(0.220)\end{array}$ & $\begin{array}{l}-0.473^{* * *} \\
(0.221)\end{array}$ & $\begin{array}{l}-0.495^{* *} \\
(0.220)\end{array}$ & $\begin{array}{l}-0.530^{* *} \\
(0.220)\end{array}$ \\
\hline External Financial Dependance & $\begin{array}{l}0.070^{*} \\
(0.041)\end{array}$ & $\begin{array}{l}0.070^{*} \\
(0.041)\end{array}$ & $\begin{array}{l}0.075^{*} \\
(0.040)\end{array}$ & $\begin{array}{l}0.071^{*} \\
(0.041)\end{array}$ \\
\hline$\beta_{E M}$ & & $\begin{array}{l}0.111 \\
(0.244)\end{array}$ & & \\
\hline$\beta_{E M}$ & & & & $\begin{array}{l}0.370 \\
(0.277)\end{array}$ \\
\hline$\beta_{\text {World }}$ & & & & $\begin{array}{l}-0.325^{*} \\
(0.183)\end{array}$ \\
\hline Number of Countries & 6 & 6 & 6 & 6 \\
\hline Observations & 857 & 857 & 857 & 857 \\
\hline $\mathrm{R}^{2}$ & 0.02 & 0.02 & 0.02 & 0.04 \\
\hline
\end{tabular}

This table reports the OLS coefficients of a regression where the dependent variable is the CAR of each firm in the 2 days following the announcement of each country's inclusion in the corresponding index. The explanatory variables are: Financial, which is an indicator variable that is equal to 1 for financial firms; Government-Related, which is an indicator variable that is equal to 1 for government-related firms; Tradable, which is an indicator variable equal to for firms in tradable industries (according to the classification in Mian and Sufi (2014)); External Financial Dependance, which is a measure of firms' dependance on external financing sources, computed following Rajan and Zingales (1998); $\beta_{\mathrm{EM}}$, which is the estimated sensitivity of each firm's returns to the returns of the MSCI Emerging Markets Index in the year preceding the announcement, and; $\beta_{\text {World, }}$ which is the estimated sensitivity of each firm's returns to the returns of the MSCI World Index in the year preceding the announcement. CARs in the first two columns are computed estimating a 1-factor model where the only risk factor is the return of the MSCI Emerging Markets Index. CARs in the last two are computed estimating a 2-factor model where the risk factors are the return of the MSCI Emerging Markets Index and the return of the MSCI World Index. Observations in the top and the bottom percentile of the country-specific distribution of 2-day cumulative abnormal returns are excluded. Standard errors in parenthesis are clustered at the country-by-industry level. ${ }^{*},{ }^{* *}, * * *$, denote significance at the $10 \%, 5 \%$, and $1 \%$ confidence level, respectively.

Table A6

Changes in betas.

\begin{tabular}{|c|c|c|c|}
\hline \multicolumn{4}{|c|}{ Changes in Firms' $\beta s$ after the Announcement Date } \\
\hline & \multirow{2}{*}{$\frac{1 \text {-Factor Model }}{\Delta \beta_{E M}}$} & \multicolumn{2}{|c|}{ 2-Factor Model } \\
\hline & & $\Delta \beta_{E M}$ & $\Delta \beta_{\text {World }}$ \\
\hline Financial & $\begin{array}{l}0.004 \\
(0.062)\end{array}$ & $\begin{array}{l}-0.018 \\
(0.053)\end{array}$ & $\begin{array}{l}0.039 \\
(0.056)\end{array}$ \\
\hline Government-Related & $\begin{array}{l}-0.047 \\
(0.056)\end{array}$ & $\begin{array}{l}-0.024 \\
(0.051)\end{array}$ & $\begin{array}{l}-0.040 \\
(0.058)\end{array}$ \\
\hline Tradable & $\begin{array}{l}-0.017 \\
(0.046)\end{array}$ & $\begin{array}{l}-0.005 \\
(0.045)\end{array}$ & $\begin{array}{l}-0.019 \\
(0.053)\end{array}$ \\
\hline External Financial Dependance & $\begin{array}{l}0.001 \\
(0.006)\end{array}$ & $\begin{array}{l}0.002 \\
(0.005)\end{array}$ & $\begin{array}{l}-0.001 \\
(0.007)\end{array}$ \\
\hline Constant & $\begin{array}{l}-0.008 \\
(0.030) \\
\end{array}$ & $\begin{array}{l}0.011 \\
(0.028) \\
\end{array}$ & $\begin{array}{l}-0.034 \\
(0.042) \\
\end{array}$ \\
\hline Number of Countries & 6 & 6 & 6 \\
\hline Observations & 697 & 697 & 697 \\
\hline $\mathrm{R}^{2}$ & 0.00 & 0.00 & 0.00 \\
\hline
\end{tabular}

This table reports the OLS coefficients of a regression where the dependent variable is the change in the estimated sensitivity of firms to a risk factor - the return of the MSCI Emerging Markets Index in the first two columns and the return of the MSCI World Index in the third column - in the two years around the announcement of each country's inclusion in the corresponding index. $\Delta \beta_{\mathrm{j}}$ is calculated as the estimated sensitivity of each firm's returns to the returns of risk factor $j$ - either the return of the MSCI Emerging Markets Index or the return of the MSCI World Index - in the year following the announcement minus the estimated sensitivity to the same factor in the year preceding the announcement. The explanatory variables are: Financial, which is an indicator variable that is equal to 1 for financial firms; Government-Related, which is an indicator variable that is equal to 1 for government-related firms; Tradable, which is an indicator variable equal to for firms in tradable industries (according to the classification in Mian and Sufi (2014)); and External Financial Dependance, which is a measure of firms' dependance on external financing sources, computed following Rajan and Zingales (1998). In the first column, we estimate a 1-factor model where the only risk factor is the return of the MSCI Emerging Markets Index. In columns (2) and (3) we estimate a 2-factor model where the risk factors are the return of the MSCI Emerging Markets Index and the return of the MSCI World Index. Standard errors in parenthesis are clustered at the country-by-industry level. *, ${ }^{* *}$, ***, denote significance at the $10 \%, 5 \%$, and $1 \%$ confidence level, respectively. 


\section{References}

Akinci, O., 2017. A Note on the Estimation of the Atemporal Elasticity of Substitution Between Tradable and Nontradable Goods. mimeo.

Alfaro, L., Kalemli-Ozcan, S., Volosovych, V., 2014. Sovereigns, upstream capital flows, and global imbalances. J. Eur. Econ. Assoc. 12, $1240-1284$.

Alfaro, L., Chari, A., Kanczuk, F., 2017. The real effects of capital controls: firm-level evidence from a policy experiment. J. Int. Econ. 108, 191-210.

Altavilla, C., Pagano, M., Simonelli, S., 2017. Bank exposures and sovereign stress transmission. Rev. Finance 21, 2103-2139.

Andrade, S.C., Chhaochharia, V., 2018. The costs of sovereign default: evidence from the stock market. Rev. Financ. Stud. 31, $1707-1751$.

Arellano, C., Bai, Y., Bocola, L., 2017. Sovereign default risk and firm heterogeneity. NBER Working Papers 23314. National Bureau of Economic Research, Inc.

Arslanalp, S., Tsuda, T., 2014. Tracking global demand for emerging market sovereign debt. IMF Working Papers 14/39. International Monetary Fund.

Bank for International Settlements (BIS), 2019. Monetary Policy Frameworks in EMES: Inflation Targeting, the Exchange Rate and Financial Stability. Annual Economic Report.

Basak, S., Pavlova, A., 2013. Asset prices and institutional investors. Am. Econ. Rev. 103, 1728-1758.

Baskaya, Y.S., di Giovanni, J., Kalemli-Ozcan, S., Peydro, J.-L., Ulu, M.F., 2017. Capital flows and the international credit channel. J. Int. Econ. 108, 15-22.

Becker, B., Ivashina, V., 2018. Financial repression in the european sovereign debt crisis. Rev. Finance 22, 83-115.

Benigno, G., Converse, N., Fornaro, L., 2015. Large capital inflows, sectoral allocation, and economic performance. J. Int. Money Financ. 55, 60-87.

Blanchard, O., Ostry, J.D., Ghosh, A.R., Chamon, M., 2017. Are capital inflows expansionary or Contractionary? Theory, policy implications, and some evidence. IMF Econ. Rev. 65, 563-585.

Borri, N., Shakhnov, K., 2018. Limited participation and local currency sovereign debt. Unpublished, available at SSRN. https://ssrn.com/abstract=2978127.

Bottero, M., Lenzu, S., Mezzanotti, F., 2020. Sovereign debt exposure and the bank lending channel: impact on credit supply and the real economy. J. Int. Econ., Forthcoming 126.

Broner, F., Erce, A., Martin, A., Ventura, J., 2014. Sovereign debt Markets in Turbulent Times: creditor discrimination and crowding-out effects. J. Monet. Econ. 61, $114-142$.

Broner, F., Clancy, D., Erce, A., Martin, A., 2019. Fiscal multipliers and foreign Holdings of Public Debt. Working Paper Series 2255. European Central Bank.

Cakici, N., Fabozzi, F.J., Tan, S., 2013. Size, value, and momentum in emerging market stock returns. Emerg. Mark. Rev. $16,46-65$.

Calomiris, C.W., Larrain, M., Schmukler, S.L., 2020. Capital inflows, equity issuance activity, and corporate investment. J. Finan. Inter., Forthcoming.

Chari, A., Blair Henry, P., 2008. Firm-specific information and the efficiency of investment. J. Financ. Econ. 87, 636-655.

Chari, A., Henry, P.B., 2004. Risk sharing and asset prices: evidence from a natural experiment. J. Financ. 59, 1295-1324.

Chari, A., Leary, R., Phan, T., 2018. The costs of (sub)sovereign default risk: Evidence from Puerto Rico. Working Paper 18-3, Federal Reserve Bank of Richmond.

Chen, H., Noronha, G., Singal, V., 2004. The Price response to S\&P 500 index additions and deletions: evidence of asymmetry and a new explanation. J. Financ. 59, 1901-1930.

Cremers, M., Ferreira, M.A., Matos, P., Starks, L., 2016. Indexing and active fund management: international evidence. J. Financ. Econ. 120, 539-560.

Dittmar, R.F., 2008. Do sovereign bonds benefit corporate bonds in emerging markets? Rev. Financ. Stud. 21, $1983-2014$.

Du, W., Schreger, J., 2016. Local currency sovereign risk. J. Financ. 71, 1027-1070.

Gabaix, X., Maggiori, M., 2015. International liquidity and exchange rate dynamics. Q. J. Econ. 130, 1369-1420.

Gennaioli, N., Martin, A., Rossi, S., 2014. Sovereign default, domestic banks, and financial institutions. J. Financ. 69, 819-866.

Gopinath, G., Boz, E., Casas, C., Díez, F.J., Gourinchas, P.-O., Plagborg-Moller, M., 2020. Dominant currency paradigm. Am. Econ. Rev. $110,677-719$.

Greenwood, R., 2005. Short- and long-term demand curves for stocks: theory and evidence on the dynamics of arbitrage. J. Financ. Econ. 75, 607-649.

Greenwood, R., Vayanos, D., 2010. Price pressure in the government bond market. Am. Econ. Rev. 100, 585-590.

Hacibedel, B., van Bommel, J., 2007. Do Emerging Markets Benefit from Index Inclusion? Money Macro and Finance (MMF) Research Group Conference 2006128 (Money Macro and Finance Research Group).

Harris, L., Gurel, E., 1986. Price and volume effects associated with changes in the S\&P 500 list: new evidence for the existence of Price pressures. J. Financ. 41, 815-829. Hau, H., 2011. Global versus local asset pricing: a new test of market integration. Rev. Financ. Stud. 24, 3891-3940.

Hau, H., 2014. The exchange rate effect of multi-currency risk arbitrage. J. Int. Money Financ. 47, 304-331.

Hau, H., Massa, M., Peress, J., 2010. Do demand curves for currencies slope down? Evidence from the MSCI global index change. Rev. Financ. Stud. 23, 1681-1717.

Hébert, B., Schreger, J., 2017. The costs of sovereign default: evidence from Argentina. Am. Econ. Rev. 107, 3119-3145.

Henry, P.B., 2000. Stock market liberalization, economic reform, and emerging market equity prices. J. Financ. 55, 529-564.

Hofmann, B., Shim, I., Shin, H.S., 2019. Bond risk premia and the exchange rate. BIS Working Papers 775, Bank for International Settlements.

Kashyap, A.K., Kovrijnykh, N., Li, J., Pavlova, A., 2018. The benchmark inclusion subsidy. NBER Working Papers 25337. National Bureau of Economic Research, Inc.

Kohn, D., 2015. Addicted to debt: foreign purchases of U.S. treasuries and the term-premium. Department of Economics Working Papers 2015-1. Universidad Torcuato Di Tella.

Kolasa, M., Wesolowski, G., 2020. International spillovers of quantitative easing. J. Int. Econ., Forthcoming 126.

Krishnamurthy, A., Vissing-Jorgensen, A., 2011. The effects of quantitative easing on interest rates: channels and implications for policy. Brook. Pap. Econ. Act. 42, 215-287.

Krishnamurthy, A., Nagel, S., Vissing-Jorgensen, A., 2017. ECB policies involving government bond purchases: Impact and channels. NBER Working Papers 23985. National Bureau of Economic Research, Inc.

Lane, P.R., McQuade, P., 2014. Domestic credit growth and international capital flows. Scand. J. Econ. 116, $218-252$.

Larrain, M., 2015. Capital account opening and wage inequality. Rev. Financ. Stud. 28, 1555-1587.

Mian, A., Sufi, A., 2014. What explains the 2007-2009 drop in employment? Econometrica 82, 2197-2223.

Morelli, J., Perez, D., Ottonello, P., 2019. Global banks and systemic debt crises. 2019 Meeting Papers 644. Society for Economic Dynamics.

Obstfeld, M., Rogoff, K., 1995. Exchange rate dynamics Redux. J. Polit. Econ. 103, 624-660.

Ongena, S., Popov, A., Horen, N.V., 2019. The invisible hand of the government: moral suasion during the European sovereign debt crisis. Am. Econ. J. Macroecon. 11, 346-379.

Pandolfi, L., Williams, T., 2019. Capital flows and sovereign debt markets: evidence from index Rebalancings. J. Financ. Econ. $132,384-403$.

Pandolfi, L., Williams, T., 2020. Real effects of sovereign debt inflows. AEA papers and proceedings. Forthcoming 11, $511-515$.

Patel, N., Welch, I., 2017. Extended stock returns in response to S\&P 500 index changes. Rev Asset Pric Stud 7, 172-208.

Priftis, R., Zimic, S., 2020. Sources of borrowing and fiscal multipliers. The Economic Journal Ueaa051.

Raddatz, C., Schmukler, S., Williams, T., 2017. International asset allocations and capital flows: the benchmark effect. J. Int. Econ. 108, 413-430.

Rajan, R.G., Zingales, L., 1998. Financial dependence and growth. Am. Econ. Rev. 88, 559-586.

Sander, N., 2019. Causal Effects of Capital Inflows. mimeo.

Schnabl, P., 2012. The international transmission of Bank liquidity shocks: evidence from an emerging market. J. Financ. 67, 897-932.

Shleifer, A., 1986. Do demand curves for stocks slope down? J. Financ. 41, 579-590.

Vayanos, D., Vila, J.-L., 2009. A preferred-habitat model of the term structure of interest rates. CEPR Discussion Papers 7547, C.E.P.R. Discussion Papers.

Warnock, F., Warnock, V., 2009. International capital flows and U.S. interest rates. J. Int. Money Financ. 28, 903-919.

Williams, T., 2018. Capital inflows, sovereign debt and bank lending: micro-evidence from an emerging market. Rev. Financ. Stud. 31, 4958-4994. 